\title{
SUNZI VERSUS XUNZI: TWO VIEWS OF DECEPTION AND INDIRECTION
}

\author{
Lisa Raphals*
}

\begin{abstract}
This article examines two views of the ethics and efficacy of deception. The Sunzi is famous for its praise of deception and indirect strategy in warfare. This explicit praise of deception distinguishes it from other Militarist texts, which either reject deception or advocate it only as a practical and important strategic tool. The Xunzi rejects deception and indirection in both civil and military contexts. The Sunzi and Xunzi's attitudes toward deception and indirection thus represent opposite poles within Chinese philosophical thought.
\end{abstract}

This article examines two extreme views of the ethics and efficacy of deception. The Sunzi is famous (or infamous) for its advocacy of deception and indirect strategies in warfare. Its explicit advocacy of deception distinguishes it from other Militarist texts, which either reject deception or advocate it in practical terms as an important strategic tool. Xunzi by contrast rejects deception and indirection outright in both civil and military contexts. Sunzi and Xunzi thus represent opposite poles within Chinese philosophical thought in their attitudes toward the use of deception and indirection, and this is the interest in a comparison between them. Xunzi's critique of deception in a military context is also important because it marks the beginning of a long history of Confucian criticism of the Sunzi.

I begin with a general account of some problems associated with deception and then turn to three aspects of deception in the Sunzi. In the second section, I show that deception is central to the Sunzi's strategy-based approach to warfare and that that approach often involves indirect action. I then contrast the Sunzi account of deception to those of other Militarist texts and examine the kinds of indirect action recommended by Sunzi and other Militarist texts. These differ in important ways from a different kind of indirect action associated with wu wei 無為 or "acting without acting" in Warring States thought. In the

\footnotetext{
* Lisa Raphals, 瑞麗, University of California, Riverside; email: lisa.raphals@ucr. edu.
}

(C) The Society for the Study of Early China and Cambridge University Press 2016 
third section I consider several attacks on deception in the Xunzi. I begin with Xunzi's complex attitude toward artifice (wei 偽) in order to introduce a central distinction in Xunzi's view between destructive artifice linked to deception and positive uses of artifice by sages. I then turn to Xunzi's attack on military deception in "Debating Military Affairs" (Yi bing 議兵), followed by his broad philosophical attack on deception in political and philosophical contexts.

\section{Deception}

A substantial scholarship in both Chinese and comparative philosophy examines problems of self-deception, but deception of others has received less attention. Self-deception is an important philosophical topic in Confucian ethics (as an aspect of self-cultivation). ${ }^{1}$ It is equally important, albeit for different reasons, in Greek philosophy, where it is closely associated with the problem of akrasia (literally lack of mastery) or weakness of will. ${ }^{2}$ Greek and Roman philosophers take a range of positions on deception, from Plato's "Noble Lie" (gennaion pseudon, Rep. III $414 \mathrm{~b}-\mathrm{c}$ ) which is justifiable when the end justifies the means, to Augustine's "On Lying," which rejects lying under all circumstances. Augustine presents a typology of eight kinds of lies, of which seven are cases in which ends are claimed to justify means. Augustine argues that these are essentially unwilling lies because the lie is a means, not an end. One type is put forth for the sheer pleasure of falsehood, and this is the real lie. ${ }^{3}$

There is also a substantial contemporary Western philosophical literature on lying and deception. Some of it is primarily concerned with concrete and practical situations, in advertising, the media, politics, and medicine, and is not relevant here (beyond perhaps its general ignorance of the Sunzi view of deception). Of more interest is a literature within analytic philosophy that goes to great pains to define both lying and

1. See Antonio S. Cua, "Self Deception," in Encyclopedia of Chinese Philosophy, ed. Antonio S. Cua (London: Routledge, 2003), 670-78, and Roger T. Ames and Wimal Dissanayake, eds., Self and Deception: A Cross-Cultural Philosophical Enquiry (Albany: State University of New York Press, 1996).

2. In Plato's Protagoras (358d) Socrates claims that akrasia does not exist because no one willingly goes toward the bad. Aristotle (Nicomachean Ethics VII.1-10) disagrees. For him, akratic individuals disregard what reason dictates they should do for reasons that include emotional influences but also self-deception.

3. Augustine, "On "Lying," in Treatises on Various Subjects, in Fathers of the Church, ed. R. J. Deferrari, vol. 16 (New York: Fathers of the Church, 1952): 86-88. For discussion see Harry G. Frankfurt, On Bullshit (Princeton: Princeton University Press, 2005), 56-59. 
deception. Several observations from this literature contribute to an understanding of key differences between the Sunzi and Xunzi on deception. By contrast, there is very little contemporary scholarship on the topic of the deception of others within Chinese philosophy. Some scholarship on the Xunzi takes up the question of artifice, but it is not centered on the question of deception.

\section{Deception and Lying}

Much of the analytic literature on lying and deception focuses on problems of the truth or falsity of statements, and is less interested in the implications of true or false statements for action. ${ }^{4}$ For example, Thomas L. Carson defines deception as "intentionally causing someone to have a false belief that the deceiver believes to be false."5 This point underlies an important difference between deception and lying. Deception is always intentional. By contrast, a lie can be told in error. A false statement can be made by someone who believes it to be true; or an intended lie may turn out to be true. In other words, a lie may be told by accident.

Deception also implies success in ways that lies do not. There must be (or persist) a false belief, to count as deception. ${ }^{6}$ By contrast, intentionally false statements count as lies whether or not they succeed in deceiving their intended (or unintended) audiences.

Another important difference between deception and lies is that deception is not limited to intentionally false statements, or even to any statement (false or true). Deception may consist in deliberate omission, or in the introduction of misleading information. It can take the form of lying, misleading, omission, and misrepresentation, including causing someone to persist in a false belief. ${ }^{7}$ It can also include what the eminent contemporary philosopher Harry G. Frankfurt calls "bullshit." Frankfurt describes bullshit as a misrepresentation of a speaker's nature or intentions. Unlike lies, it does not misrepresent a state of affairs or a speaker's beliefs about them, but rather his or her enterprise. A bullshitter "misrepresents what he is up to." ${ }^{8}$ Frankfurt is more critical

4. See Frankfurt, On Bullshit; Thomas L. Carson, Lying and Deception: Theory and Practice (Oxford: Oxford University Press, 2010), especially 46-50; and James E. Mahon, "A Definition of Deceiving," International Journal of Applied Philosophy 21 (2007), 181-94, and "The Definition of Lying and Deception," Stanford Online Encyclopedia of Philosophy [accessed February 2008].

5. Carson, Lying and Deception, 46.

6. For deception as successful see Gilbert Ryle, The Concept of Mind (London: Hutchinson, 1949), 130, and Carson, Lying and Deception, 46.

7. Carson, Lying and Deception, 47-50, Mahon, "A Definition of Deceiving," 189-90.

8. Frankfurt, On Bullshit, 54 . 
of the bullshitter than of the liar, because the latter at least recognizes (and thus respects) the truth, while the bullshitter is indifferent to it. ${ }^{9}$

Finally, it is striking that this scholarship addresses deception primarily in the form of false or misleading statements, rather than misleading actions.

\section{Deception and Indirection}

Deception can involve indirection, and some definitions of indirection specifically allude to it. The Oxford English Dictionary defines the noun indirection as (1): "indirect movement or action; a devious or circuitous course to some end ... an indirect or devious way." This meaning emphasizes indirect means to an end, and is not pejorative. But a second meaning stresses deceptive uses of indirect means (2): "Want of straightforwardness in action; an act, or practice, which is not straightforward and honest; deceit; malpractice."10

Indirection can be used to create misleading perceptions (that a road is empty, that an army is disordered). Three points are important in considering relationships between indirection and deception. First, deception is always deliberate and linked to specific goals and desires. Second, while it may seem spontaneous or accidental, it is carefully planned. Third, indirection is not inherently deceptive, though it may be subtle or difficult to perceive.

\section{The Sunzi on Deception and Indirection}

Although the Sunzi has received more attention than other Militarist texts, it can no longer be perceived as representative of the bingfa 兵法 ("art of war") genre. For purposes of this discussion I use the terms Militarist text and bingfa to refer to six texts: the Sun Bin bingfa 孫臏兵法 and the five preHan "military classics": the Sunzi bingfa 孫子兵法, [Taigong] Liutao [太公] 六轁, Sima fa 司馬法, Wuzi 吳子, and Wei Liaozi 尉繚子. Our understanding of these materials is significantly indebted to the evidence of military texts excavated from Linyi 臨沂, Shandong in 1972, including versions of the Sunzi bingfa, the Sun Bin bingfa, and sections from the Wei Liaozi. ${ }^{11}$

9. Frankfurt, On Bullshit, 53-56.

10. "Indirection, n." OED Online. September 2015. Oxford University Press. http:// www.oed.com/view/Entry/94533?redirectedFrom=indirection\&. [accessed September 2015]

11. For the Sunzi see Yinqueshan Han mu zhujian zhengli xiaozu, Sunzi bingfa 孫子 兵法 (Beijing: Wenwu, 1976). For additional accounts see Zhan Libo 詹立波, “Luetan 
The Sunzi advocates an approach to warfare whereby strategy (mou 謀) is more important than military strength. This strategy-based approach relies on the assessment ( $j i$ 計) of factors that can be used to calculate prospects for victory. Assessment involves forethought (lï 慮) that makes possible several kinds of prediction. Some are empirical, such as probable weather, conditions of terrain, and the best routes. Such information permits quantitative predictions about material, troop numbers, and supplies. Other predictions are psychological. Understanding an enemy general well enough to predict his reactions makes it possible to mislead him in ways that create the circumstances for victory.

Thus the strategy-based approach of the Sunzi centrally recommends and even depends upon the use of deception and trickery ( $g u i$ 詭, zha 詐) to manipulate the perceptions and state of mind of the enemy general as a key component in obtaining victory. The Sunzi general does this by psychological manipulations based on deception. He provides false clues, engages in misleading troop movements, and uses spies to introduce false information.

Deception in the Sunzi is also related to a very particular account of indirection. The Sunzi emphasizes the importance of indirection, but it is important to understand what this notion does and does not mean. The Sunzi and other Militarist texts emphasize the importance of mastering both direct and indirect modes of action, and give detailed accounts of extraordinary or oblique ( $q i$ 奇) modes of efficacious action.

Militarist accounts of indirection differ in important ways from the very influential Warring States notion of wu wei. Warring States texts that discuss wu wei disagree on how to attain it and what it should be used for, but they agree that it is an extraordinarily efficacious mode

Linyi Han mu zhujian Sunzi bingfa" 略談臨沂漢幕竹簡孫子兵法, Wenwu 12 (1974), 1319; Sunzi jiaoshi 孫子校釋, ed. Wu Jiulong 吴九龙 et al. (Beijing: Junshi kexue, 1990); and Li Ling 李零, Sunzi guben yanjiu 孫子古本研究 (Beijing: Beijing daxue, 1995), 207-23. For the Sun Bin see Sun Bin bingfa 孫臏兵法 (Beijing: Wenwu, 1975). For the Wei Liaozi and other Militarist texts see Yinqueshan Han mu zhujian zhengli xiaozu, “Yinqueshan jianben Wei Liaozi shiwen (fu jiaozhu)" 銀雀山本 尉繚子釋文(附校注) Wenwu 1977.2, 21-27; "Linyi Yinqueshan zhushu shou fa, shou ling, deng shisan pian" 臨沂銀雀山竹書守法守令等十三篇, Wenwu 1985.4，27-37; Yinqueshan Han mu zhujian 銀雀山漢墓竹簡 (Beijing: Wenwu, 1985); and Wu Jiulong, Yinqueshan Han jian shiwen 銀雀山漢簡釋文 (Beijing: Wenwu, 1985). For discussion of these materials see Michael Loewe, "Manuscripts Found Recently in China: A Preliminary Survey," T'oung Pao 63 (1977), 131-35; Robin D. S. Yates, "New Light on Ancient Chinese Military Texts: Notes on Their Nature and Evolution, and the Development of Military Specialization in Warring States China," T'oung Pao (2nd ser.) 74.4/5 (1988), 211-48; and Mark Edward Lewis, "Writings on Warfare Found in Ancient Chinese Tombs," Sino-Platonic Papers 158 (2005), 1-15. 
of action that somehow accomplishes goals without desire or effort. Differences between Militarist indirect action and wu wei are important both for understanding deception in the Sunzi and for a broader understanding of wu wei in Warring States thought.

\section{Strategy and Assessment}

The Sunzi begins with a claim that prospects for victory can be assessed or calculated:

故經之以五事, 校之以計, 而索其情, 一曰道, 二曰天, 三曰地, 四曰將, 五曰法。

Therefore structure it by five factors, evaluate it by assessment, and thus seek to determine its essentials. The first is dao; the second is Heaven [climate and weather]; the third is Earth [terrain]; the fourth is Command; the fifth is Law [regulation]. ${ }^{12}$

Assessment requires foreknowledge (xian zhi 先知):

故明君賢將, 所以動而勝人, 成功出於眾者, 先知也。先知者, 不可取於 鬼神, 不可象於事, 不可驗於度, 必取於人, 知敵之情者也。

Thus, the means by which the enlightened ruler and worthy general set into motion and gain victory and achieve things beyond the multitude is foreknowledge [xian zhi]. Foreknowledge is not received from ghosts and spirits, from images of [past] matters or from [calendrical] calculation $[d u]$. It must come from those who understand the enemy's true situation. ${ }^{13}$

Calculation (suan 笄) is carried out in the ancestral temple, but it is important to emphasize that this knowledge does not come from mantic practices or calendric calculation. ${ }^{14}$ Other elements of assessment

12. Sunzi bingfa 孫子兵法 (Shiyi jia zhu Sunzi jiao li 十一家注孙子校理, Beijing: Zhonghua, 1999), 1.2. Translations are my own unless otherwise specified, but are indebted to Samuel B. Griffith, Sun Tzu: The Art of War (London and New York: Oxford University Press, 1963), and Roger T. Ames, Sun Tzu: The Art of Warfare (New York: Ballantine, 1993). These translations are referenced hereafter as Griffith and Ames.

13. Sunzi bingfa, 13.290 (Ames, 169; Griffith, 144-45).

14. For quantitative calculations in the temple see Sunzi bingfa, 1.20. For discussion of the meaning of this phrase, and accounts of transition from mantic procedures to rational calculation see Ames, 283; Griffith, 71. See also Albert Galvany, "Signs, Clues and Traces: Anticipation in Ancient Chinese Political and Military Texts," Early China 38 (2015), 151-93; Robin McNeal, Conquer and Govern. Early Chinese Military Texts from the Yizhou shu (Honolulu: University of Hawai'i Press, 2012), 11721; and Ralph D. Sawyer, The Seven Military Classics of Ancient China (Boulder: Westview Press, 2003), 437, n. 21. 
are empirical: knowledge of local weather patterns, information on roads and terrain (possibly obtained from local guides), and knowledge on troop numbers, supplies, and movements (possibly obtained from spies).

Assessment and foreknowledge are also psychological because, to know which strategies will be effective, it is necessary to understand the enemy. ${ }^{15}$ The general is enjoined to "know the enemy and know yourself" (zhi bi zhi ji 知彼知已). ${ }^{16}$ This knowledge includes the temperament of the enemy general and the discipline and loyalty of his troops. Understanding the enemy makes possible the strategic use of deception to create the circumstances for victory. The strategist general uses deception to disguise his capabilities and situation, feigning (in)capacity; (in)activity; disguising his location, etc. This secrecy ensures that the enemy will not know what to defend or attack. ${ }^{17}$ Deception thus creates favorable circumstances for victory. Used together, foreknowledge, strategy and deception allow the strategist general to control the encounter and either bring the enemy to him or prevent the enemy from engaging. ${ }^{18}$ The Sunzi describes this as "the method of attacking by strategy" (mou gong zhi fa 謀攻之法). ${ }^{19}$

Chapter 3, "Attack by Strategy" (Mou gong 謀攻), emphasizes the importance of attacking the enemy's strategy. ${ }^{20}$ It claims that a skilled general can subdue the enemy without fighting, capture his cities without siege, and conquer his country without protracted warfare. These arguments are based on claims in Chapter 2 that the most effective military action is swift and minimally destructive. Alastair I. Johnston has questioned this specifically non-violent account of Sunzi strategy, and argues that the Sunzi valorizes violence far more than is generally recognized. ${ }^{21}$ What is important about these claims for the present discussion is not whether the Sunzi lives up to ethical or practical claims to minimize violence and destruction in warfare, but rather its specific claim that strategy is the key element in military victory. This view also distinguishes the Sunzi from other Militarist texts, which describe

15. Sunzi bingfa, 3.67 and 6.120.

16. Sunzi bingfa, 3.62. The same phrase appears at 10.230.

17. Sunzi bingfa, 1.14-19 and 6.105-16, respectively.

18. Sunzi bingfa, 6.105-7.

19. Sunzi bingfa, 3.52.

20. 故上兵伐謀. Sunzi bingfa, 3.46. “Therefore the best military [action] is to attack the enemy's strategy (故上兵伐謀), next is to attack alliances, next is to attack the troops, and worst is to besiege walled cities" (Sunzi bingfa, 3.46-48, Ames, 111).

21. Alastair I. Johnston, Cultural Realism: Strategic Culture and Grand Strategy in Chinese History (Princeton: Princeton University Press, 1995). 
tactics at great length, but put less emphasis on the central role of strategy.22

It is striking that the Sunzi repeatedly uses numbered lists—often of three, five, or nine items-to present much of the information that forms the basis of assessment and calculation. For example, it describes "five factors" (wu shi 五事) and "five deliberations" (wu ji) for assessing prospects for victory, and five qualities of good command. ${ }^{23}$ It describes three ways a ruler can harm an army and five essentials for victory. ${ }^{24}$ Military methods also come in a list of five: (1) measurement (of space), (2) estimation (of quantities), (3) calculations, (4) comparisons, and (5) (chances of) victory. ${ }^{25}$ To make the best use of troops the general must understand "Nine Transformations" (Jiu bian) and "five dangers" (wu wei 五危). ${ }^{26}$ Even "Attack by Fire" (Huo gong 火攻) comes in a list of five methods. ${ }^{27}$ These lists are elaborated by explanations of each term, but never by anecdotes or detailed illustrations.

These laconic lists resemble what Matthias Richter has described as pragmatic texts for selecting officials: these "catalogs" enumerated (un)desirable qualities for individuals in government service. Richter argues that pragmatic texts were integrated into larger compilations that are now read inappropriately as philosophical works. But the form of argument of the Sunzi is closer to the "catalog" lists than are most early Chinese philosophical texts. ${ }^{28}$

According to Richter, such texts claim that their methods for evaluating human talent allow them to "recognize" ( $z h i$ 知) talent, "distinguish" (bian 辨) the fit from the unfit, and “obtain" (de 得) individuals of

22. For the Sun Bin see Joseph Needham, Robin D. S. Yates, et al., Science and Civilisation in China, Volume V Part 6 (Cambridge: Cambridge University Press, 1994), 22, and Ames, Sunzi, 29-41. Although the Liutao is concerned with strategy, much of the book is concerned with detailed tactics (Sawyer, Seven Military Classics, 33-35). The Wuzi (Sawyer, Seven Military Classics, 202-5) also focuses on specific topics of central military interest, such as controlling the army, responding to change, and stimulating officers. The Sima fa and Wei Liaozi are primarily concerned with military administration and focus on the moral virtues of military leadership (Sawyer, Seven Military Classics, 116-19 and 232-38, respectively). The hostility of these two texts to deceptive strategy is discussed below.

23. Sunzi bingfa, 1.2-8.

24. 軍之所以患于君者三 Sunzi bingfa, 3.57. 勝者有五. Sunzi bingfa, 3.59.

25. 一曰度, 二曰量, 三曰數, 四曰稱, 五曰勝. Sunzi bingfa, 4.76-77, Griffith, 88.

26. Sunzi bingfa, 8.167-72 and $176-78$.

27. 火攻有五. Sunzi bingfa, 12.276-78.

28. Matthias L. Richter, "Handling a Double-edged Sword: Controlling Rhetoric in Early China," Asiatische Studien/Études Asiatiques 68.4 (2014), 1021-68, especially 1023-24. 
ability. ${ }^{29}$ The Sunzi also uses the language of acquisition or attainment. The general is enjoined to "know" (zhi) the five factors, five deliberations, three ways in which an army may be harmed by the ruler, and the five essentials for victory. He must know the "Nine Transformations" (Chapter 8) to obtain the best advantage from his men. ${ }^{30} \mathrm{He}$ obtains (de) results from the advantages of heaven and earth and from calculations in the temple. ${ }^{31} \mathrm{He}$ also uses schemes and deceptions to obtain the enemy's plans; and employs local guides to obtain (de) the advantages of terrain and circumstance. ${ }^{32}$

Richter emphasizes that our reading practices of Warring States texts tend to isolate their philosophical context from their concrete and practical concerns. This approach is instructive for the Sunzi because of its many practical concerns. It shares these concerns with other Militarist texts, but the Sunzi is distinctive for its explicit theory that combines strategy-based warfare and informed deception as the basis of effective strategy.

\section{Deception in the Sunzi}

The Sunzi strongly recommends the use of deception in connection with assessment (ji) forethought (lii) and stratagem (mou). Two passages make the explicit claim that deception is central to success in warfare:

兵者, 詭道也

Warfare is the way of deception. ${ }^{33}$

故兵以詐立

In warfare, practice dissimulation. ${ }^{34}$

Explicit praise of deception is rare; these two passages are the sole instances of the use of the terms gui 詭 (deception) and zha 詐 (ruse, trickery) in the Sunzi.

Although deceit is central to the strategic method of the Sunzi, it is rarely mentioned directly. The Sunzi illustrates the use of deception and cunning, but rarely mentions it. For example, immediately after the claim that warfare is based on deception:

29. Richter, "Handling a Double-edged Sword," 1023.

30. Sunzi bingfa, 8.172.

31. Sunzi bingfa, 1.9 and 20, respectively.

32. Sunzi bingfa, 6.120 and 7.141, respectively. When ten or more chariots have been

taken, those who took the first should obtain reward (Sunzi bingfa, 2.38).

33. Sunzi bingfa, 1.12 (Ames, 104; Griffith, 66).

34. Sunzi bingfa, 7.142 (Ames, 130; Griffith, 106). 
利而誘之, 亂而取之, 實而備之, 強而避之, 怒而撓之, 卑而驕之, 佚而 勞之, 親而離之, 攻其不備, 出其不意。此兵家之勝, 不可先傳也。

Offer profit and tempt him; feign disorder and strike him. When he is concentrated, prepare against him; when he is strong, avoid him. Anger [his general] and confuse him. Feign inferiority and pump up his arrogance. When he is at peace, belabor him. When his army is as close as a family, divide it. Attack where he is unprepared; go forth where he does not expect you. These are the strategist's keys to victory. It is not possible to discuss them beforehand. ${ }^{35}$

Rather than presenting a defense or explanation of deception, this passage provides an explanation of how to use it effectively. The passage also emphasizes the spontaneous nature of "the strategist's keys to victory": they cannot be discussed beforehand.

Nonetheless, the Sunzi repeatedly describes deceptive strategies. For example, "Weakness and Strength" (Xu shi 虛實) describes a skilled general using deception to control the battlefield by bringing the enemy to him in the circumstances of his choice. ${ }^{36}$ He uses deception to offer an apparent advantage with the result that the enemy does not know where to attack or defend. ${ }^{37}$ His interest in manipulating the perceptions of others extends to his own troops. "Nine Kinds of Ground" (Jiu di 九地) emphasizes this point:

\section{易其事, 革其謀, 使人無識, 易其居, 迂其途, 使人不得慮。}

By changing his arrangements and altering his strategies, he keeps people in the dark. By changing his camp and making his route roundabout $[y u]$, he ensures that they will not be able to anticipate $[l i i]$ him. ${ }^{38}$

The passage continues that he deliberately leads his men into danger and only then shows his hand: leading his troops into battle is like climbing a height and throwing away the ladder; he leads his troops deep in and only then releases the trigger. ${ }^{39}$ The chapter summarizes these skills as "the ability to accomplish your purposes by cunning" (qiao neng cheng shi 巧能成事). ${ }^{40}$

It is striking that Sunzi descriptions of how to use deception or protect against it never take the form of the anecdotes, dialogues, or teaching stories typical of many Masters texts. To put it another way, the Sunzi

35. Sunzi bingfa, 1.14-19 (Ames, 104-5; Griffith, 66-71).

36. 故善戰者, 致人而不致于人. Sunzi bingfa, 6.106 (Ames, 126; Griffith, 96).

37. Sunzi bingfa, 6.116-17.

38. Sunzi bingfa, 11.252-53 (Ames, 159; Griffith, 136).

39. Sunzi bingfa, 11.254 .

40. Sunzi bingfa, 11.264. 
general is described as an expert, but not as a teacher. Although stories set in the form of a "teaching mode" have a long history that probably dates back to the Analects, this mode of narrative never appears in the Sunzi. Sun $\mathrm{Wu}$ 孫武, the apocryphal author of the Sunzi, is never presented as an authoritative teacher, or in any other kind of dialogue with either a student or potential patron. ${ }^{41}$ Teaching scenes can establish the authority of a master, the nature of instruction, and sometimes the unsuitability of a student. ${ }^{42}$ Despite the subtlety of the skills being recommended, none of this appears in the Sunzi. Instead, deception is presented through laconic accounts of what could be called acting by contraries through the use of deception and stratagem to mislead an opponent. Interestingly, methods of deception are not presented as numbered lists of the kind identified by Richter and discussed above.

\section{Deception in Other Militarist Texts}

Militarist texts present a spectrum of attitudes toward deception. At one end the Sunzi centrally and consistently advocates it. At the other the Wei Liaozi and Sima fa explicitly reject it. The Sun Bin, Wuzi, and Liutao take an intermediate position.

According to the Wei Liaozi:

先王之所傳聞者, 任正去詐, 存其慈順, 決無留刑。故知道者, 必先圖不 知止之敗, 惡在乎必往有功。

The reason the former kings are still heard about is that they appointed the upright [ren zheng] and eliminated the deceitful [qu zha]. They always preserved their benevolence and obedience but were decisive and unremitting in punishments. One who understands the dao of war invariably plans ahead [xian $t u$ ] against the defeats that arise from not knowing where to stop. ${ }^{43}$

This view is unequivocal. The Sima fa focuses more on administration, and discipline than on strategy, and emphasizes the divergent values of

41. For the history of such teaching scenes see Mark Edward Lewis, Writing and Authority in Early China (Albany: State University of New York Press, 1999), 61-62.

42. For detailed discussion in the context of the Zhuangzi see Carine Defoort, "Instruction Dialogues in the Zhuangzi: An 'Anthropological' Reading," Dao 11 (2012), 459-78.

43. Wei Liaozi, 2 ("Bing tan" 兵談), B12/27/13-14, trans. after Sawyer, Seven Military Classics, 262. For citations to the Wei Liaozi, Wuzi, and Sima fa see D. C. Lau 劉殿爵, Ho Che Wah 何志華, and Chen Fong Ching 陳方正, eds., A Concordance to the Militarists 兵書四種逐字索引 (ICS series, Hong Kong: Commercial Press, 1992) B (Wei Liaozi: 15-35) C (Wuzi: 36-44) and D (Sima fa: 45-52). For translation see Sawyer, Seven Military Classics. This is the only occurrence of the terms gui, wei, or zha in the Wei Liaozi. 
the civil and martial realms of society (wen and $w u$ 文物). But that separation does not extend to the recognition of any virtue in deception:

上不尊德而任詐厨, 不尊道而任勇力, 不貴用命而貴犯命, 不貴善行而貴 暴行, 陵之有司, 此謂少威。

When superiors do not respect virtue but employ deception and evil [zha ni]; when they do not honor dao but employ courage and strength; when they do not value those who obey commands but esteem those who contravene them; when they do not value good actions but esteem violent behavior so that [the people] insult minor officials: this is called diminished awesomeness [shao wei]. ${ }^{44}$

The Sima fa criticizes both excess and deficiency of "awesomeness" (wei 威). Excess instills fear and works against righteousness and good administration; deficiency is linked to the employment of destructive officials. Both the Wei Liaozi and Sima fa set up an opposition between negative moral values associated with deception (zha) and positive ones associated with uprightness (zheng, Wei Liaozi) or virtue (de 德, the Sima fa).

A third view is to emphasize the use of benevolence and other nonmartial virtues, but to allow for, and rationalize, the use of deception under limited circumstances. This is the view of the Sun Bin bingfa, Wuzi, and Liutao.

The Sun Bin bingfa emphasizes set formations and the specialization of the general, and focuses on specific tactics rather than broad issues. ${ }^{45} \mathrm{At}$ several points it recommends deception to mislead an enemy general. In the chapter "Questions of King Wei" (Wei wang wen 威王問) King Wei asks Sun Bin how to employ troops in different situations, two of which involve deception. Sun Bin advises a commander with superiority in numbers and strength to feign poor discipline in order to encourage the enemy's ambitions. ${ }^{46}$ For an equally matched opponent, his advice is to dazzle him to make him divide his forces. But to work, this plan must be kept secret. ${ }^{47}$ The chapter concludes with four urgent considerations in warfare:

44. Sima fa, 2 (“Tian zi zhi yi" 天子之義), D2/47/8-9, trans. after Sawyer, Seven Military Classics, 131. This is the only occurrence of the terms gui, wei, or zha in the Sima fa.

45. Sun Bin bingfa jiao li 孫臏兵法校理 (ed. Zhang Zhenze 張震澤, Beijing: Zhonghua, 1984). I have consulted D. C. Lau and Roger T. Ames, Sun Pin: The Art of Warfare (Albany: SUNY Press, 2003). See also Ralph D. Sawyer, Sun Pin: Military Methods (Boulder: Westview Press, 1995).

46. Sun Bin bingfa jiao, 3.25 (Lau and Ames, Sun Pin, 99).

47. Sun Bin bingfa jiao li, 3.25-26 (Lau and Ames, Sun Pin, 100). 
田忌曰：「權、埶（勢）、謀、詐，兵之急者邪？」

孫子曰: 「非也。夫權者, 所以聚眾也。埶 (勢) 者, 所以令士必鬥也; 謀者, 所以令適（敵）无備也; 詐者, 所以困適（敵）也; 可以益勝, 非 其急者也。」

Tian Ji asked: "Are weighing the opportune moment [quan], strategic advantage [shi], planning [mou] and deception [zha] the most urgent matters in military operations?"

Master Sun [Bin] replied: "Not at all. Weighing the opportune moment is the means to bring together the troops. Strategic advantage is the means to ensure that the soldiers will fight. Planning is the means to ensure that the enemy is unprepared. Deception is the means to harass the enemy. They can facilitate victory, but they are not the most urgent matters." 48

The chapter "Coordinating Military Assignments" (Guan yi 官一) recommends the use of "hidden schemes and strategic deceptions" (yin ni mou zha 隱匿謀詐) to lure the enemy into battle. ${ }^{49}$ The final chapter of the Sun Bin, "Extraordinary and Straightforward" (Qi zheng 奇正) recommends the combination of straightforward (zheng) and extraordinary (qi) strategies:

刑 (形) 以應刑 (形), 正也; 無刑 (形) 而裚 (制) 刑 (形), 奇也。奇 正無窮, 分也。

Using form [xing] to respond to form is straightforward [zheng]. Using what has no form to dominate that which has form by means of that which has no form is extraordinary [qi]. Extraordinary and straightforward are inexhaustible because [troops] can be divided. ${ }^{50}$

These topics are not pursued and there is little emphasis on deception or extraordinary (qi) methods, compared to the Sunzi. (Extraordinary methods are discussed further below.) As Lau and Ames point out, misrepresenting one's strength to confuse the enemy falls short of the sweeping claim in the first chapter of the Sunzi that the art of war is the art of deception. ${ }^{51}$

Deception first appears in the $W u z i$ in a discussion of five reasons for going to war and five types of army associated with each: (1) a righteous (yi 義) army, motivated by desire for fame; (2) a strong (jiang 彊) army, motivated by desire for profit; (3) a hard (gang 剛) army, motivated by

\footnotetext{
48. Sun Bin bingfa jiao li, 3.27-28 (Lau and Ames, Sun Pin, 102).

49. Sun Bin bingfa jiao li, 14.99 (Lau and Ames, Sun Pin, 184).

50. Sun Bin bingfa jiao li, 31.193 (Lau and Ames, Sun Pin, 175).

51. Lau and Ames, Sun Bin, 39.
} 
hatred; (4) a fierce (bao 暴) army, motivated by internal discord; and (5) a contrary ( $n i$ 逆) army, motivated by famine. Each has its proper mode of attack, and one is ruses and trickery:

五者之數, 各有其道, 義必以禮服, 德必以謙服, 剛必以辭服, 暴必以詐服, 逆必以權服。

Of these five headings, each has its own way. For the righteous you must use ritual to make them submit. For the strong you must use deference to make them submit. For the hard you must use persuasive language to make them submit. For the fierce you must use ruses [zha] to make them submit. For the contrary you must use weighing the opportune moment [quan] to make them submit. ${ }^{52}$

In one case trickery is described as appropriate to the character of a particular state. Marquis $\mathrm{Wu}$ 武候 asks Wu Qi 吳起 for advice when he is beset by six states (Qin, Chu, Zhao, Qi, Yan, and Han) in all four directions and the configuration of power (shi $\mathrm{i}$ 勢) is not to his advantage. $\mathrm{Wu}$ Qi describes the character of each state and how best to address it, including by deception.

He describes the people of Qin as strong, with treacherous land, severe government and a contentious population who believe in rewards and punishments. They are prone to scatter and engage in individual combat; and are best attacked by false prospects for profit, which makes greedy soldiers abandon their general. With this ruse one can hunt down scattered soldiers, set up ambushes, take advantage of the moment, and capture their general..$^{53}$ By contrast, the people of Yan are sincere, straightforward, and careful: "they love courage and right conduct and rarely use deceptions and stratagems" (zha mou 詐謀). ${ }^{54}$ They defend their positions but are not mobile; and are best attacked from behind. Another passage emphasizes the need to understand the talents ( $c a i$ 才) of the enemy general and weigh the opportune moment according to the situation (yin xing yong quan 因形用權):

其將愚而信人, 可詐而誘; 貪而忽名, 可貨而賂; 輕變無謀, 可勞而困。

If their general is stupid and trusts others he can be deceived [zha] and misled [wei]. If he is greedy and neglectful of his reputation he can be gifted and bribed. If he is easily led and has no strategy he can be belabored and harassed. ${ }^{55}$

52. Wuzi, C1/36/31-32 ("Tu guo" 圖國) (Sawyer, Seven Military Classics, 208).

53. Wuzi, C2/37/31, ("Liao di" 料敵) (Sawyer, Seven Military Classics, 210-11).

54. Wuzi, $\mathrm{C}_{2} / 38 / 2$, ("Liao di") (Sawyer, Seven Military Classics, 211).

55. Wuzi, $\mathrm{C}_{4} / 4^{1} / 17-18$ ("Lun jiang" 論將) (Sawyer, Seven Military Classics, 218). 
In summary, the Wuzi does not recommend deception as a military virtue, but does recommend it as a practical means to gain information about an enemy or to capture an enemy general.

The most extensive discussion of deception occurs not in the Sunzi but in the Liutao, which repeatedly discusses deception (gui), artifice (wei), and trickery (zha). Overall, the Liutao recommends the use of benevolence and wisdom, but takes the latter to include using deception to gain victory with minimal violence. Several passages illustrate this important point.

“The King's Wings" (Wang yi 王翼) is a discourse on selecting officials. Several official roles explicitly use deception.

腹心一人主潛謀應卒, 揆天56消變, 㧾攬計謀, 保全民命。

謀士五人主圖安危，慮未萌，論行能，明賞罰，授官位，決嫌疑，定可否。

The Chief of Planning, one, is in charge of secret plans [qian mou] and sudden responses; investigating Heaven so as to negate sudden changes; directing and supervising schemes and stratagems [ji mou] and protecting and preserving and maintaining the lives of the people.

Planning Officers [mou shi], five, are in charge of planning [ $t u]$ for safety and danger, anticipating events before they happen [lï wei ming, lit. that have not yet germinated], discoursing on conduct and ability, making clear rewards and punishments, appointing official positions, deciding what is doubtful, and establishing what is and is not permissible.

伏鼓旗三人主伏鼓旗, 明耳目, 詭符節, 謬號令, 闇忽往來, 出入若神。

Secret Signals Officers, three, are in charge of keeping secret [the signals of] drums and banners, being clear [in signals] to the eyes and ears, being deceptive with seals and tallies [gui fu jie], speaking false commands and orders [miи hao ling], going and coming with stealth $[a n]$ and haste, going in and out like spirits.

遊士八人主伺姦候變，開閏人情，觀敵之意，以為間諜。

Traveling Officers, eight, are in charge of awaiting [spying out] misdeeds [jian] and transformations, manipulating [lit. opening and closing] emotions, and assessing the enemy's intentions, in order to act as spies.

術士二人主為譎詐, 依託鬼神, 以惑眾心。

56. I read 夫 as 天, following Taigong liutao jinzhu jinyi 太公六韜今註今譯, ed. Xu Peigen 徐培根 (Taipei: Taiwan shangwu, 1976), 106 (“Wang yi” 王翼). This is also clearly Sawyer's reading (Seven Military Classics, 6o). 
Technical Officers, two persons, in charge of deploying ruses and tricks [jue $z h a$ ] and for calling on ghosts and spirits in order to delude the minds of the people. ${ }^{57}$

These five types of officer all are responsible for the maintenance and manipulation of secret plans, foreknowledge, deceptive signals and communications, and spycraft in several specific military contexts. In another passage King Wu 武王 asks about selecting generals, and the Taigong 太 公 explains fifteen cases where external appearance does not reflect internal character, of which two are particularly relevant. The ninth seems guileless but is untrustworthy (you er bu xin zhe 有悾悾而不信 者). The eleventh seems to lack eloquence but is a person of merit and achievement (you gui ji er you gongxiao zhe 有詭激而有功效者). ${ }^{58}$

The chapter titled “The Unorthodox Army" (Qi bing 奇兵) describes indirect strategies that use deception to confuse an enemy army. For example, deep grass permits concealed escape; narrow passes and mountain forests allow a small force to attack a large one:

詭伏設奇、遠張詿誘者, 所以破軍擒將也;

Using deceptive ambushes and preparing unorthodox [methods], stretching out distant formations to deceive and entice the enemy, these are means by which to destroy the enemy's army and capture its general.

偽稱敵使者, 所以絕糧道也; 謬號令, 與敵同服者, 所以備走北也;

Disguising [wei] some men as enemy emissaries is the means by which to sever their supply lines. Forging [enemy] commands and orders and wearing the same clothes as the enemy are the means by which to be prepared for their retreat. ${ }^{59}$

The chapter "Fullness and Emptiness" (Ying $x u$ 盈虛) describes a conversation between King Wen 文王 and the Taigong about the sage rulers of antiquity. The Taigong describes Yao as acting by wu wei (discussed below) and encouraging the virtuous: "He becalmed his heartmind and put all the nodes [of social forms] into correct alignment [zheng jie 正節]. He used laws and measures to prohibit evil and artifice [xie wei 邪偽]."60

In "Honoring the Worthy" (Shang xian 上賢), when King Wen asks about appointing officials, the Taigong urges him to get rid of the

57. Taigong liutao 太公六鞱 (Sibu congkan 四部叢刊 edn.), 3.9b-10a (“Wang yi” 王翼) (Sawyer, Seven Military Classics, 60-62).

58. Taigong liutao, 3.10b ("Xuan jiang" 選將) (Sawyer, Seven Military Classics, 63).

59. Taigong liutao, 3.13a ("Qi bing" 奇兵) (Sawyer, Seven Military Classics, 70-71).

6o. 平心正節, 以法度禁邪偽. Taigong liutao, 1.3b (“Ying xu” 盈虛) (Sawyer, Seven Military Classics, 42-43). 
deceptive and artful (zha wei 詐偽). He expounds on "Six Thieves" and "Seven Harms." The latter include those who:

朴其身躬, 惡其衣服; 語無為以求名, 言無欲以求利, 此偽人也, 王者慎 勿近。

[third]: they are simple in appearance, wear bad clothes, speak of wu wei to seek a reputation and discourse on non-desire to seek profit. These are persons of artifice; kings should be careful not to let them near.

偽方異伎, 巫疊左道, 不祥之言, 幻惑良民, 王者必止之。

[seventh]: they create fang recipes and weird techniques, engage in $w u$ arts, $g u$ poison and heterodox daos, they promulgate inauspicious sayings, and confuse and trouble honest people. Kings must stop them. ${ }^{61}$

Several other passages provide workaday details on how to deceive enemy troops. For example, to determine whether a fortification is empty or inhabited, listen for drums and bells and look for birds startled into flight; if there are no vapors overhead, the enemy has tricked you with dummies (zha er wei ou ren 詐而為偶人). ${ }^{62}$ In another passage King Wu asks about a small army facing a larger foe deep in enemy territory. The Taigong advises finding an opportunity to trick the enemy (zha di 詐敵) and escape quickly. If the enemy cannot be deceived, the only recourse is to spend money to gain intelligence from spies. ${ }^{63}$ Finally, King $\mathrm{Wu}$ asks how to attack a large force with a small one, absent advantages of terrain, timing, and alliances. Here the Taigong recommends deception in order to manipulate the situation:

妄張詐誘, 以熒惑其將。迂其道, 令過深草; 遠其路, 令會日路。

Set our specious arrays and false enticements [zha you] to mislead their general. Make his path roundabout and force him to pass tall grass. Make his way longer to force an encounter at sunset. ${ }^{64}$

In summary, the Sunzi stands apart from both other Militarist texts and Chinese philosophical literature in its treatment of deception. Only the Sunzi explicitly theorizes deception as a central principle of its strategy-centered approach to warfare. Nonetheless, it makes sparing use of the language of deception and trickery (gui, zha), and

61. Taigong liutao, 1.5b (“Shang xian” 上賢) (Sawyer, Seven Military Classics, 49).

62. Taigong liutao, 4.19b ("Lei xu" 壘虛) (Sawyer, Seven Military Classics, 88).

63. Taigong liutao, 5.21b-22a ("Niao yu ze bing" 鳥雲澤兵) (Sawyer, Seven Military Classics, 93).

64. Taigong liutao, 5.22a ("Shao zhong" 少眾) (Sawyer, Seven Military Classics, 94-95). 
prefers detailed instructions on how to deceive an enemy general. Such instructions have many parallels in other bingfa texts.

\section{Indirection and Wu wei}

The discussion of deception above makes clear that at least some strategies require indirect or roundabout action to bring about the deceptions so central to Sunzi strategy. But what kind of indirection does the Sunzi recommend, and how does it compare to other Warring States accounts of indirection, specifically accounts of wu wei? This question is important because of recent scholarship on the nature of wu wei and how it is understood.

Several recent studies have emphasized its phenomenological and cognitive aspects, and suggest that $w u$ wei is more a state of mind than a mode of action. For example, Pang Pu 龐朴 describes wu wei not as a form of action but as: "the state of vital energies and spirit at the exact moment of action." 65 Jean François Billeter makes a distinction between "reflexive" (réflexif) and active (actif) modes of action, and describes the actions and expertise of Cook Ding as "the idea of perfect action" (l'idée de l'activité parfaite): a perfect efficacy and economy of energy. ${ }^{66}$ Edward Slingerland argues that the attainment of "effortless action" was a central Warring States religious and philosophical ideal. He describes wu wei as "an almost supernatural efficacy" in which actions flow freely from spontaneous inclinations but accord perfectly with the dictates of the situation. ${ }^{67}$

As an example, Billeter describes the expertise of the craft experts of the Zhuangzi (who presumably use wu wei), not as a transitory state or "skill," but rather as a set of dispositions that have been completely transformed. The story of Cook Ding provides an example in which "an artisan of genius" minutely describes the experience of his proper craft. As his mastery progresses:

65. 行之時為之際的精神状态. Pang Pu 龐朴 “Jie niu zhi jie” 解牛之解, Xueshu Yuekan 學术月刊 3 (1994), 11-20, 15.

66. Jean François Billeter, "Pensée occidentale et pensée chinoise: le regard et l'acte," in Différences, Valeurs, Hierarchie: Textes Offerts à Louis Dumont, ed. JeanClaude Galey (Paris: École des Hautes Etudes en Sciences Sociales, 1984), 25-51, 47 and 5o. Slingerland cites this study in his account of wu wei, but Billeter's discussion of Cook Ding never actually refers to wu wei. See Edward T. Slingerland, Effortless Action: Wu-wei as Conceptual Metaphor and Spiritual Ideal in Early China (New York, Oxford: Oxford University Press, 2003), 8.

67. Slingerland, Effortless Action, 5 and 7. 
the growing efficacy of the activity on the objective plane is accompanied by a growing sense of ease and happiness on the subjective plane. The rapport between object (the ox to which he applies the butcher's art) and subject (the subjectivity of the butcher in action) changes to the degree that the cook progresses in his art. ${ }^{68}$

Billeter argues that in the Zhuangzi, this state of mind is linked a particular version of egalitarianism in which domination is not the be-all and end-all of human relationships: "other relations than power of one over another are possible, and that they are in conformity with the very essence of human subjectivity." 69

Slingerland goes further and argues that wu wei was both a spiritual ideal and philosophical problematique in the Analects, Laozi, Mengzi, Zhuangzi, and Xunzi. ${ }^{70}$ Importantly, these texts are conventionally considered both Daoist and Confucian. Some of his claims rest on arguments from conceptual metaphor theory. Wu wei does not occur in the Mencius and rarely in the Xunzi, but on Slingerland's account, these texts contain conceptual metaphors for "effortless action."71 The issue of conceptual metaphor theory is beyond the scope of the present discussion, so I restrict myself to actual instances of the term $w u$ wei and the claims of Pang $\mathrm{Pu}$, Billeter, and Slingerland that it describes a state of mind, rather than an explicit mode of action, in order to understand how it differs from the Sunzi account of indirect action.

A few examples illustrate the centrality of accounts of indirect action, described as wu wei, in Warring States thought. Analects 15.5 describes Shun as "one who ruled by means of wu wei" (wu wei er zhi zhe 無為 而治者). He made himself reverent, took up his [ritual] position facing south, and that was all. ${ }^{72}$ This passage seems to emphasize that Shun

68. Billeter, "La phenomenologie de l'activité dans le Zhuangzi," Asiatische Studien $47 \cdot 4$ (1993), 545-58, 552.

69. Billeter, "Non-pouvoir et non-vouloir dans le Zhuangzi: un paradigme," Asiatische Studien 50.4 (1996, 853-80), 875-76, cf. 877-78.

70. Slingerland, Effortless Action, 5, cf. 294-96.

71. Slingerland, Effortless Action, 10. For this point see Chris Fraser, "On Wu-Wei as a Unifying Metaphor," Philosophy East and West 57.1 (2007), 97-106, 97-98.

72. Lun yu jishi 論語集釋, ed. Cheng Shude 程樹德 (4 vols., Beijing: Zhonghua, 1996), 31.1062. Warring States texts give two distinct accounts of what ruling by wuwei might mean. It may refer to a ruler who has perfected himself and thus can transform others without deliberate action, as here. In his commentary to Analects 7.1 the Ming scholar Wang Fuzhi 王夫之 (1619-1692) likens Shun's ruling by wu wei to Confucius' claim at Analects 7.1 that he does not innovate (Lun yu jishi 13.431-36). Alternatively, if a ruler has chosen able ministers, they can govern effectively without his intervention. For this passage see Slingerland, Effortless Action, 175-76. 
did not "do" anything: wu wei consisted in orienting himself correctlymentally and physically—and that was all. ${ }^{73}$

Claims for the efficacy of wu wei are especially prominent in the Daode jing where those who understand dao:

損之又損之, 以至於無為。無為無不為。

take away more and more in order to arrive at a state acting by not acting [wu wei]. By acting without acting there is nothing that is not done. ${ }^{74}$

Here it is not clear whether wu wei is a disposition of mind or an indirect mode of action, for example governing through ministers, and much depends on how we read the Daode jing. By contrast, the Zhuangzi seems to describe wu wei as both an attitude of mind and a mode of action. The chapter "Perfect Happiness" describes it thus:

吾以无為誠樂矣, 又俗之所大苦也. 故曰, 「至樂无樂, 至譽无譽。」

天下是非果未可定也。雖然, 無為可以定是非。至樂活身, 唯無為幾存。 請嘗試言之。天無為以之清, 地無為以之寧, 故兩無為相合, 萬物皆化。 芒乎芴乎, 而無從出乎! 芴乎芒乎, 而無有象乎! 萬物職職, 皆從無為 殖。故曰: 「天地無為也, 而無不為也。」人也, 就能得無為哉!

I consider wu wei to be true happiness, but ordinary people consider it bitter. Therefore they say: perfect happiness is without happiness; perfect praise is without praise.

What the world takes to be right and wrong can never be finally settled. Nonetheless, wu wei can be used to establish right and wrong. Perfect happiness is to preserve the self alive, and only wu wei comes close. Let me try to put this into words. Heaven through wu wei arrives at purity; Earth through wu wei arrives at tranquility. Therefore the two wu weis conjoin and the myriad things transform. ${ }^{75}$

The Guanzi seems to contain two distinct accounts of effective action. The "Art of War" (Bing fa) chapter resembles the Sunzi in its recommendations for speed in battle and deceiving the enemy:

遠用兵, 則可以必勝。.. 善者之為兵也, 使敵若據虛, 若搏景。無設無形

焉, 無不可以成也。無形無為焉, 無不可以化也。

73. For more on the importance of "correct alignment" (zheng) in this context see Lisa Raphals, "Uprightness, Indirection, Transparency," in Dao Companion to the Analects, ed. Amy Olberding (Dordrecht: Springer, 2014), 159-70.

74. Boshu Laozi jiaozhu 帛书老子校注, ed. Gao Ming 高明 (Beijing: Zhonghua, 1996), 48.54.

75. Zhuangzi jishi 莊子集釋, ed. Guo Qingfan 郭慶藩 (Beijing, Zhonghua, 1961), 18.611 . 
If the armed forces are employed with speed, victory will be certain.... Those who are skillful at manipulating armed forces are ones who cause the enemy to act as if they were grasping at empty air and striking at shadows. It has neither fixed place nor form, yet there is nothing it does not achieve. It has neither form nor action, yet there is nothing it does not transform. Such is dao. It appears lost and yet it is there. It appears to be behind and yet it is to the fore. The [mere] prestige [of being a prince] is inadequate to command it. ${ }^{76}$

By contrast, in the "Art of the Heartmind" (Xin shu 1) chapter of the Guanzi, wu wei seems to be a quality of a sage:

故必知不言無為之事, 然後知道之紀。

Therefore one must understand the unspoken word and handle affairs by wu wei. Thereafter one may know guidelines of $d a{ }^{77}$

是以君子不休乎好, 不迫乎惡, 恬愉無為, 去智與故。

Thus, the junzi is not to be enticed by liking or oppressed by dislike. He is contented, acts without acting [wu wei], and eliminates wisdom and pretense. $^{78}$

According to Explanation VII, the dao of Heaven is vacuous and formless, so nothing opposes it; it flows everywhere and never changes:

德者道之舍, 物得以生。生知得以職道之精。故德者得也, 得也者, 其謂 所得以然也, 以無為之謂道, 舍之之謂德。

Power [de] is a dwelling of dao. Things must obtain it in order to live. The living must know how to obtain it in order to grasp the essence of dao. Therefore, power is obtaining, and obtaining refers to obtaining the means by which things are as they are. When it acts by wu wei, we call it dao. When it dwells in things, we call it power. ${ }^{79}$

What is important for the present discussion is that wu wei-whether understood as action or mindset-is described as indirect, spontaneous, 
and effortless. The Daode jing, Zhuangzi, and Guanzi all specifically describe it as removed from desires and intentions. ${ }^{80}$

\section{Militarist Accounts of Direct and Indirect Actions}

The Sunzi account of indirect or extraordinary action differs significantly from Warring States accounts of indirect action as wu wei. The Sunzi argues that effective strategy requires both indirect and straightforward modes of action, described by two sets of antonyms: $q i$ 奇 and zheng 正 (indirect and direct, extraordinary and straightforward) and $y u$ 迁 and zhi 直 (indirect or roundabout and straight). "Strategic Advantage" (Bing shi 兵勢) includes a sustained discussion of when to use direct and indirect methods of attack:

可使必受敵而無敗者, 奇正是也。

What makes the army capable of withstanding the enemy attack and not be defeated is a matter of indirect and direct [qi zheng] operations. ${ }^{81}$

Neither method is inherently preferred; the important point is to know when to do what. This important point is overlooked by François Jullien in his account of Chinese and Greek military operations in Detour and Access. He is right to emphasize the importance of $q i-$ the indirect-in military matters. But the antithesis he claims between a Greek or Western polemical directness (with no place for Trojan horses) and an imagined Chinese universal indirection loses sight of the complementarity of two modes of combat in which: "the indirect and direct produce each other" (qi zheng xiang sheng 奇正相生). ${ }^{82}$

A few examples illustrate this point. "Military Combat" (Jun zheng 軍爭) asserts that the difficulty of combat consists in "turning the roundabout into the direct" (yi yu wei zhi 以迂為直) and turning misfortune into advantage. ${ }^{83}$ Therefore it is important that deliberations take account of both methods:

故迂其途, 而誘之以利, 後人發, 先人至, 此知迂直之計者也。

Thus makes his road roundabout, entice $[y o u]$ him with the prospect of

80. For example, "The person of highest virtue acts without acting [wu wei] and holds nothing in regard" (wu wei er wu yi wei 無為而無以為, Daode jing 38). The Daode jing recommends indirect action: "Do that which consists of not doing (wei wu wei); act in a way that is not acting (shi wu shi 事無事)," Daode jing 63.

81. Sunzi bingfa, 5.86 .

82. François Jullien, Detour and Access: Strategies of Meaning in China and Greece, trans. Sophie Hawkes (New York: Zone Books, 2000); Sunzi bingfa, 5.69.

83. Sunzi bingfa, 7.135 (Ames, 129; Griffith, 102). 
profit; and you can set out after him but arrive before him. Someone who can do this is one who understands the calculation of indirect and direct [yu zhi]. ${ }^{84}$

Here, "indirect" consists of a roundabout route that presents a false appearance of advantage. In other words, indirection is at least to some extent deception. A later passage in the same chapter emphasizes the need for foreknowledge to assess the right mixture of straight and roundabout methods:

\section{懸權而動，先知迂直之計者勝，此軍爭之法也。}

Ponder and deliberate and then move. One who has foreknowledge of the assessment of direct and indirect will be victorious. This is the method of armed combat. ${ }^{85}$

The term wu wei does not appear in the Sunzi, Wuzi, Sima fa, Wei Liaozi, or Sun Bin bingfa. It does appear in the Liutao, but in descriptions of the actions of sages or their imitators, not of generals. For example, one passage describes Yao as acting by wu wei: he did not impose untimely labor service and "reduced his desires, constrained his will, and managed affairs by wu wei." 86 In another he attributes it to the efficacious action of Heaven under the rule of a sage:

\section{夫民化而從政。是以天無為而成事，民無與而自富。此聖人之德也。}

When the people are transformed and follow their government, in this way Heaven acts by wu wei and brings affairs to completion. The people are without allegiances and so enrich themselves. This is the power of the sage. ${ }^{87}$

Finally, in "Honoring the Worthy" the Taigong advises King Wen against the artifices of those who affect simplicity and speak of wu wei in order to seek fame and profit. ${ }^{88}$ These passages describe $w u$ wei as a principle of sage rulership, not as a principle of strategy or indirection.

These examples show that the actions and skills of the Sunzi general differ from those associated with wu wei in three ways. First, whereas wu wei is spontaneous and not premeditated, the apparent spontaneity of the Sunzi general is not spontaneous or effortless. Rather, it is the

84. Sunzi bingfa, 7.135 (Ames, 129; Griffith, 102).

85. Sunzi bingfa, 7.145 (Ames, 130; Griffith, 106).

86. 削心約志, 從事乎無為. Taigong liutao, 1.3b (“Ying xu”) (Sawyer, Seven Military Classics, 42).

87. Taigong liutao, 2.8a ("Wen qi" 文啟) (Sawyer, Seven Military Classics, 55).

88. Taigong liutao, 1.5b ("Shang xian") (Sawyer, Seven Military Classics, 49), discussed above. 
result of protracted and deliberate forethought, analysis, and manipulation. The Sunzi general may employ natural patterns, but for different reasons and in different ways than does the agent of wu wei. A second difference concerns desires and intentions. Wu wei is described repeatedly as removed from desires and intentions. Chris Fraser modifies Slingerland's account to identify wu wei with the absence of action motivated by an agent's desires, will, ambition, knowledge, and education; but here too the Sunzi general is distinguished by his desires, ambitions, and training because his actions arise directly from the intention and desire for victory. ${ }^{89}$ Third, deception is key to the false appearances engineered by the Sunzi general. The absence of wu wei as a mode of indirection in the Sunzi or other Militarist texts is all the more striking in the light of Slingerland's claims for the importance of $\mathrm{w} u$ wei as a central concept and ideal among Warring States thinkers, including those conventionally identified as both Daoist and Confucian, and central to the development of Warring States thought. ${ }^{90}$ By contrast, the Sunzi describes indirect action merely as an effective method of deception, with no inherent value or efficacy in itself.

Further, the three themes of strategy, deception, and indirect action are central and interrelated concepts in the Sunzi, in ways that distinguish it from other Militarist texts. The Sunzi repeatedly recommends skills and virtues associated with strategy to anticipate events and the use of deception and indirection to mislead both the enemy general and one's own troops.

Finally, it is worth noting that the deceptive strategies recommended in the Sunzi clearly conform to deception as defined by contemporary philosophers. Sunzi deception is deliberate, successful, and not confined to, or particularly reliant on, lying. It can include "bullshit" (on Frankfurt's definition), but only insofar as it misleads effectively. Unlike much contemporary bullshit, Sunzi deceptions are not designed to enhance the image or reputation of the general who uses deceptionbased strategy.

\section{Xunzi on Deception and Artifice}

I now turn to the thoroughgoing attack on deception in the Xunzi. ${ }^{91} \mathrm{By}$ deception I again mean the core definition of deliberately creating a false

89. Fraser, "On Wu-Wei," 97.

90. Slingerland, Effortless Action, 5.

91. Xunzi jishi 荀子集釋, ed. Li Disheng 李滌生 (Taipei: Taiwan xuesheng, 1988). Translations are my own unless otherwise indicated. I have consulted John 
belief that is closely linked to action that benefits the deceiver and harms the deceived. Attacks on deception occur in the Xunzi in three distinct contexts. One is the use of deception in military operations. Military deception is addressed specifically in the chapter "Debating Military Affairs." Two others occur throughout the Xunzi. One is the attack on deception by officials, which for convenience I term political deception. A third is the promulgation of deceptive doctrines; for convenience I term this philosophical deception. These three contexts are different, in part because of different assumptions about trust. Trustworthiness is expected in government but not against an enemy. But the three overlap in Xunzi's deep distrust of deception per se, even where it may seem to be justified.

Xunzi's attitudes toward deception and artifice differ in important ways from those articulated in the Analects and Mengzi. Both attack the use of deception. Analects 1.3 suggests that a person of cunning words (qiao yan 巧言) is rarely benevolent. ${ }^{92}$ Analects 12.22 recommends "raising up the straight and setting it over the crooked." 93 Analects 13.3 stresses the importance of rectifying names (zheng ming 正名), though this is not explained in detail. ${ }^{94}$ Some passages favorably contrast a "straightforward" figure with a deceptive one in different ways. ${ }^{95}$ The Analects also makes it clear that eloquence (ning 位) is not a prerequisite for virtue $(5.5,5.15),{ }^{96}$ and that self-interested speech (li kou 利口) undermines families and states (17.18). ${ }^{97}$ A deeper view of Confucius' attitude toward deception emerges if we consider the positive connection between language and virtue in these statements. As Loy Hui-chieh points out, in addition to its suspicions of overly skillful speech, the Analects positively recommends speech that is careful and even slow. Why? This is the speech of agents who conform to their verbal

Knoblock, Xunzi: A Translation and Study of the Complete Works (3 vols. [Palo Alto: Stanford University Press, 1988, 1990, 1994], henceforward Knoblock 1, 2, and 3, respectively) and Eric L. Hutton, Xunzi 荀子: The Complete Text (Princeton, Princeton University Press, 2014, henceforward Hutton).

92. Lun yu jishi, 1.16 .

93. 舉直錯諸枉. Lun yu jishi, 25.873 .

94. Lun yu jishi, 26.885-86.

95. The rectitude (zheng) of Duke Huan of Qi versus the craftiness (jue) of Duke Wen of Jin (14.15, Lun yu jishi, 29.979). A junzi can be deceived (qi) but not entrapped (wang 罔, 6.26, Lun yu jishi, 12.415). A man of worth does not anticipate deceit (zha) but is alert when it occurs (14.31, Lun yu jishi, 30.1013). The stupidity of antiquity manifested as straightforwardness (zhen 直); the stupidity of the present manifests as deceit (zha, 17.16, Lun yu jishi, 35.1224).

96. Lun yu jishi, 9.294 and 10.325.

97. Lun yu jishi, 35.1225 
self-representations..$^{98}$ Speech, like other behavior, can create a false representation-like Frankfurt's "bullshit" - usually to the agent's advantage.

Mencius also criticizes deception. He describes exemplary figures as straightforward; for example, he states that the Duke of Zhou is not deceptive ( $q i$ 欺) in claiming King Wen as his model (3A1). ${ }^{99}$ Mencius claims that a superior man can be deceived ( $q i)$ but is difficult to entrap (nan wang 難国), and is without artifice or hypocrisy (wei 偽, 5A2). ${ }^{100}$ Mencius seems to make a positive correlation between virtue and a right use of language. When asked about his own particular abilities, his first response is that he "understands language" (wo zhi yan 我 知言, 2A2). ${ }^{101}$

Xunzi's attack on deception differs from both the Analects and Mencius in several ways. First, it is pervasive and systematic. Second, although both Confucius and Mencius link virtue to uses of language they consider correct, Xunzi pursues the issue of names to a much greater degree. Finally, whereas Confucius and Mencius overall oppose virtue and transparency to deception and artifice, Xunzi's view of artifice is more complex.

Xunzi's attitudes toward deception must be seen in the context of his broader views on artifice. Although Xunzi is intensely critical of some artifice, it is important to understand that he considered the right use of artifice a fundamental part of the activity of teachers and sages. Xunzi strongly opposed any attempt to root morality in the natural world, arguing that human nature is problematic (this term is explained below), and goodness results from deliberate, and artificial, conscious activity: wei 偽. As Michael Puett points out, Xunzi asserts the difference between the activity of heaven and earth and the activity of human artifice. Xunzi completely rejects the claim-variously expressed in the Lun $y u, M o z i$, and Daode jing - that sages imitate nature. ${ }^{102}$

98. For a useful discussion of this issue see Hui-chieh Loy, "Language and Ethics in the Analects," in Dao Companion to the Analects, ed. Amy Olberding (Dordrecht and New York: Springer, 2014, 137-58), 138.

99. Mengzi zhengyi 孟子正義, ed. Jiao Xun 焦循 (Beijing: Zhonghua, 1987), 10.320. Several other passages refer to dissimulations. A man who caught no birds driving a chariot according to the rules caught many by driving "deceitfully" (zha, $3 \mathrm{~B} 1)$. An advocate of the doctrines of Shen Nong claims that if his teachings were followed, there would be only one price in the market and no deceit (wei) in the state, so if even a small boy were sent to the market, no one would take advantage of him $\left(q i, 3 \mathrm{~A}_{4}\right)$.

100. Mengzi zhengyi, 18.627 .

101. Mengzi zhengyi, 6.199.

102. See Michael Puett, The Ambivalence of Creation: Debates Concerning Innovation and Artifice in Early China (Palo Alto: Stanford University Press, 2001), 65-69. 
Xunzi argues that morality is a human creation, and as such, falls under the category of artifice. ${ }^{103}$ By contrast "natural" behavior is based on the non-deliberative activity of wu wei, and Xunzi explicitly opposes any notion that sages should imitate nature or act by means of $w u$ wei. In response to a question about the origin of ritual and propriety, he replies:

凡禮義者, 是生於聖人之偽, 非故生於人之性也。故陶人埏埴而為器, 然 則器生於陶人之偽, 非故生於人之性也。故工人䟨木而成器, 然則器生於 工人之偽, 非故生於人之性也。聖人積思慮, 習偽故, 以生禮義而起法 度, 然則禮義法度者, 是生於聖人之偽, 非故生於人之性也。

In all cases, ritual and propriety are produced from the conscious and deliberate activity [wei] of sages and are not produced from people's inherent natures. Thus when potters shape clay and make vessels, the vessels are produced from the conscious and deliberate activity [wei] of the potters and not from people's inherent natures. When artisans carve wood to make implements, the implements are produced from the conscious and deliberate activity [wei] of the artisans and not from people's inherent natures. The sages accumulated reflections and thoughts and made a practice of conscious and deliberate activity and causes and effects [wei gu] in order to produce ritual and propriety and develop laws and standards. In this way, ritual, propriety, laws and standards were produced by the conscious and deliberate activity of sages, and were not produced by people's inherent natures. ${ }^{104}$

On this view, Xunzi sees the sages as training themselves to use faculties generated by Heaven. This self-cultivation process, like the training of an artisan, requires performing a highly regulated activity in a particular way. Xunzi thus ultimately does root culture in nature, despite his strong opposition to any claim that sages imitated the patterns of nature. ${ }^{105}$

To take the point further, Xunzi was a "constructivist" in the sense used by Kurtis Hagen. Constructivists assume that the patterns and

103. This point also is emphasized by Feng Yu-lan in his History of Chinese Philosophy (trans. Derk Bodde, 2 vols., 2nd ed. [Princeton: Princeton University Press, 1952], 1: 286). As Kurtis Hagen points out, it is given a slightly different twist in Kakimura Takashi 柿村峻 and Azuma Jūji's 吾妻重二 Japanese translation (Chūgoku Tetsugakushi 中國哲學史 [Tokyo: Fuzanbo, 1995], 423), emphasizing that morality is man-made (ren wei 人為), and is included in what Xunzi calls artifice. See Kurtis Hagen, "Artifice and Virtue in the Xunzi," Dao 3.1 (2003), 85-107, 89, n. 8.

104. Xunzi jishi, 23.544 (Hutton, 250; Knoblock, 3:153-54), cf. Puett, Ambivalence of Creation, 66.

105. For these points see Puett, Ambivalence of Creation, 65-69. 
categories that inform perceptions of the world arise from ongoing cultural traditions. Such cultural constructs require constant attention and management, and that "management" required particular attention to the attunement of names (zheng ming). ${ }^{106}$ Drawing on recent Japanese scholarship, Hagen argues that Xunzi's famous slogan should be understood to mean that human nature is crude or problematic, not that it is evil. ${ }^{107}$ For Xunzi, the improvement of "raw" human nature through moral cultivation required constant effort, and wei 偽, understood as the social devices designed and required to facilitate moral growth and social harmony, was a central part of that effort. ${ }^{108}$ In this sense, wei is a deliberate manipulation of others' perceptions and emotions, but it is a positive manipulation, undertaken for moral reasons.

Given the importance Xunzi attributes to artifice, it is not surprising that he is deeply concerned that this powerful faculty be used correctly. This concern is the common thread that unites his opposition to the "artifices" of military, political and philosophical deception. He rejects military deception because the generals who deploy it are not sages and it is not morally constructive. He rejects political deception because it promotes social and even economic instability. He rejects philosophical deception because heterodox theories, and the skepticism they produce, undermine custom and morality, and interfere with the use of morally constructive artifice. This point could be put differently using the language of means and ends. Xunzi approves of artifice as a means but only for morally acceptable ends. Military, political, and philosophical deception produce morally unacceptable ends, for different reasons in each case. These three topics are explored in detail in the next two sections.

\section{Military Deception}

Xunzi's hostility to military deception can be broken down into two distinct antipathies. One is the broad hostility to Militarists who "advocate warfare." A second is his rejection of deception as an aspect of military operations.

A range of Warring States thinkers attack military expertise they consider to advocate warfare, but only Xunzi specifically links this attack to

106. Hagen, "Artifice and Virtue," especially 85-86.

107. Hagen, “Artifice and Virtue," cf. Kodama Rokurō 児玉六郎, “Junshi no 'ren zhi xing e, qi shan zhe wei ye' no kaisyaku” 荀子の「人之性悪,其善者偽也」の解 釈," Kagoshima kōgyō kōtō senmon gakkō kenkyū hōkoku 8 (1973), 79-89, and Junshi no shisō 苗子の思想 (Tokyo, 1992), 19.

108. Hagen, "Artifice and Virtue," 88, cf. Itano Chōhachi 板野長八, Jukyō Seiritsushi No Kenkyū 儒教成立史の研究 (Tokyo: Iwanami Shoten, 1885)，270. 
deception. The Analects says little about warfare, but Analects 12.7 clearly states that government requires sufficient food, military expertise, and the confidence of the people, even if he ultimately considers it more expendable than food or the confidence of the people. ${ }^{109} \mathrm{~A}$ similar view appears in the Da Dai Li ji chapter "Using the Military" (Yong bing 用兵), where Confucius affirms that the sages used the military to suppress cruelty and violence. Only in later ages did rapacious men use it to kill the people and imperil the state. 110

The first attacks on aggressive warfare were Mohist. Paul van Els distinguishes three arguments that warfare harms the people in the Mohist chapters on warfare "Against Aggressive Warfare" ("Fei gong" 非攻): a "moral argument" (Chapter 17) based on humaneness and righteousness (ren yi 仁義); an "economic argument" (Chapter 18) based on the claim that war is always destructive if the true costs are accurately calculated; and a "religious argument" (Chapter 19) that warfare is against the interests of Heaven. ${ }^{111}$ Mohist economic arguments against warfare based on planning $(j i)$ and calculation $(s h u)$ claim that actual loss always outweighs anticipated gain if one accurately calculates the true costs of a military expedition. These costs include wearing out of material (arrows, flags, tents, etc.), the exhaustion and death of pack animals and people, and the loss of worshipers to the spirits. ${ }^{112}$

It is Mencius $\left(7 \mathrm{~B}_{4}\right)$ who first specifically attacks experts in military strategy:

有人曰: 『我善為陳, 我善為戰。』大罪也。國君好仁, 天下無敵焉。

There are people who say: "I am expert at military formations; I am expert at waging war." This is a grave crime. If the ruler of a state is drawn to benevolence he will have no match in the Empire. ${ }^{113}$

109. 足食。足兵。民信之矣. Lun yu jishi, 24.836.

110. 聖人之用兵也, 以禁殘止暴於天下也; 及後世貪者之用兵也, 以刚百姓, 危 國家也. Da Dai liji jiegu 大戴禮記解詁, ed. Wang Pingzhen 王聘珍 (Beijing: Zhonghua, 1983), 75.209.

111. See Paul van Els, "How to End Wars with Words," in The Mozi as an Evolving Text: Different Voices in Early Chinese Thought, ed. Carine Defoort and Nicolas Standaert (Leiden: Brill, 2013, 69-94), 86-87. The Mohist chapters distinguish between punitive warfare ( $z h u$ 誅) against guilty states—what in modern terms would be called a "just war"—and aggressive warfare (gong 攻) against innocent ones. See Mozi (Mozi zhuzi suoyin 墨子逐字索引, Institute for Chinese Studies Concordance [Hong Kong: Commercial Press, 2001]), 19.34/18.

112. Mozi, 18.31/2-20; van Els, "How to End Wars with Words," 80-81. The Mozi also addresses another point that is prominent in the Sunzi: that besieging walled cities is ineffective (Mozi, 18.31/21-22, Sunzi bingfa, 3.48).

113. Mengzi zhengyi, 28.962, trans. D. C. Lau, Mencius (New York: Penguin Books, 1970), 194 . 
This passage sets up an opposition between benevolence and expertise at warfare. When King $\mathrm{Wu}$ fought the Shang, he claimed to the people that: "I come to bring you peace, not to wage war on the people." Mencius concludes: "To wage a punitive war is to rectify. There is no one who does not wish himself rectified. What need is there for war?"114 The Xunzi continues the attack on advocating warfare, but adds two new elements: the use of deceit as a principle of warfare and the broader ethical status of deception.

Xunzi explicitly attacks deception in military strategy in Chapter 15 , "Debating Military Affairs," which details a debate between Xun Qing 荷卿 (henceforward Xunzi) and the Lord of Linwu 臨武君 (henceforward, Linwu) before the latter's patron, King Xiaocheng of Zhao 趙孝 成 (r. 265-244 B.C.E.). King Xiaocheng asks about the essential principles of warfare. Linwu's response reflects the theory and vocabulary of military writers of Xunzi's time, including concepts from the Sunzi. In the first exchange, Linwu recommends the strategic principles of taking advantage of the timeliness of Heaven (tian shi 天時) and the advantages of the earth (di li 地利), and observing enemy troop movements. Xunzi disagrees and argues that the most basic element of military activity is the unity of the people (yi $\mathrm{min}$ 壹民). If officers and people are not loyal and devoted, even a Tang or a Wu would not be sure of victory: ${ }^{115}$

故善附民者, 是乃善用兵者也。故兵要在乎善附民而已。

Hence one who is good at [obtaining] the support of the people is the expert in the use of military force. Thus the essential principle in military matters is nothing more than being good at obtaining the support of the people. ${ }^{116}$

Linwu objects that the most important element in warfare is technical knowledge of the advantage conferred by strategic configuration (shi li 勢利). He praises the use of "shifts and dissimulations" (bian zha 變詐) and specifically opposes technical expertise to loyalty:

孫吴用之無敵於天下，豈必待附民哉！

the theories of Sun [Wu (Sunzi) or Sun Bin] and Wu [Qi] are without rival in the empire; why rely on the support of the people! ${ }^{117}$

114. 征之為言正也, 各欲正己也, 焉用戰? Mengzi zhengyi, 28.962, trans. Lau, Mencius, 195. He also attributes to Confucius the view that experts in war should suffer the most severe punishments (4A14, Mengzi zhengyi, 15.516). He further claims that: "in the Springs and Autumns there are no just wars" (yi zhan 義戰, 7 B2, Mengzi zhengyi, 28.954).

115. Xunzi jishi, 15.265-66.

116. Xunzi jishi, 15.266 (Hutton, 145; Knoblock, 2:219).

117. Xunzi jishi, 15.266 (Hutton, 145; Knoblock, 2:219). 
Xunzi counters that dissimulation (zha) does not work on the army of a humane man. ${ }^{118}$ Deception only works on the lazy and weak and in situations where a ruler is separated from his subordinates and thus becomes separated from his power. ${ }^{119}$ Thus a Jie 桀 can use deceptive strategies against another Jie, but a Jie cannot deceive a Yao 堯. Xunzi argues that if the relation between superiors and inferiors-civil or military-is as unified as are parent and child, dissimulation cannot disrupt that unity. ${ }^{120}$

This passage presents two opposing views of warfare, which are elaborated in the chapter. Linwu seems to draw on the Sunzi and possibly other bingfa texts, though he does not say so explicitly. He prioritizes the areas in which they claim expertise: technical knowledge of weather and terrain, close observation of enemy movements, exploitation of circumstantial advantages, unpredictability, and deception in order to confound and surprise the enemy. Xunzi by contrast insists on the importance of devotion (qin fu 親附) to the commander, and that loyalty, rather than foreknowledge, determines military victory. ${ }^{121}$ Such loyalty is ultimately political, and is linked to good government because of the special motivation of soldiers and officials who serve a ruler like sons. ${ }^{122}$ Xunzi argues that good government is the basis for military strength because good order (or good government) is strong while disorder is weak. ${ }^{123}$ Aaron Stalnaker argues that loyalty was of central importance to Xunzi because by his time, the key political issue in Warring States China was not rebellion by subordinates but rather effective managerial control. ${ }^{124}$

Xunzi goes on to argue that strength arises from the moral qualities, correct ritual conduct, and orderly government of a good ruler. On this basis he creates an ascending moral hierarchy of military methods. Qi has its soldiers practice hand-to-hand combat. Wei uses fixed standards in selecting personnel. Qin treats its soldiers harshly and manages them with rewards and punishments. Soldiers from Qi are inferior to those of Wei, who are in turn inferior to the soldiers of Qin. These methods are inferior to regulations of a Duke Huan of Qi 齊桓公 (d. 643 в.C.E.) or a Duke Wen of Jin 晋文公 (697-628 в.C.E.),

118. 仁人之兵, 不可詐也. Xunzi jishi, 15.266.

119. 君臣上下之間, 渙然有離德者也. Xunzi jishi, 15.266-67.

120. Xunzi jishi, 15.267-69.

121. Xunzi jishi, 15.266.

122. For Xunzi's position see Aaron Stalnaker, "Xunzi's Moral Analysis of War and Some of Its Contemporary Implications," Journal of Military Ethics 11.2 (2012), 97-113, especially 99-101.

123. Xunzi jishi, 15.270

124. Stalnaker, "Xunzi's Moral Analysis of War," 99-100. 
which in turn are inferior to the benevolence and righteousness of a Tang 湯 or $\mathrm{Wu}{ }^{125}$ Xunzi's argument is that soldiers motivated by reward or profit and treated with dissimulation become secretive in their conduct. By contrast, correct ritual and right conduct ( $l i$ 禮 sand $y i$ 義) transform and unify the people, and deceptive strategies (zha, qiao) are no match for it. ${ }^{126}$

The discussion next turns to the key features of the general. Both the $X u n z i$ and Sunzi agree on the need for impartiality and clear regulations, but Xunzi stresses that a good general rejects what is dubious ( $q i$ yi 棄疑) in his knowledge and never goes too far in his actions. ${ }^{127}$ By contrast, the Sunzi general "creates victory" by engineering and manipulating uncertainty. ${ }^{128}$ The Xunzi and the Sunzi are also in agreement in other areas of military method that do not bear on cunning and deception. ${ }^{129}$ For example, they agree on the need for generous treatment of conquered populations, prisoners, and enemy soldiers, albeit for different reasons.

It is important to consider the rhetoric of the chapter. The distance between these two positions is less than Xunzi's rhetorical stance leads us to suppose. Xunzi acknowledges the necessity for military expertise and the specialists connected with it, even though he considers them less important than government based on quasi-filial loyalty. Several passages praise the skills of military specialists. A ruler whose army's rewards and punishments are well used and whose military machines, weapons, armor, and equipment are well designed will be strong; if they are defective, he will be weak. ${ }^{130}$ Xunzi also praises the Six Arts (liu shu 六術) and Five Deliberations (wu quan 五權) of effective generalship, which include skill in such areas as encampments, surveillance of the enemy, and other advance preparations. ${ }^{131}$ Likewise, the Sunzi stresses the importance of unity and the general's ability to inspire loyalty, which is an essential part of the Sunzi's first criterion for predicting victory. ${ }^{132}$ At a certain point, Linwu effectively gives up and the dialogue shifts to a teaching narrative in which King

125. Xunzi jishi, 15.274.

126. Xunzi jishi, 15.275.

127. Xunzi jishi, 15.276.

128. Sunzi bingfa, 6.120-23, discussed above.

129. For example, the Xunzi (15.277) specifies three circumstances under which a general cannot accept a ruler's orders: he cannot be forced to take an untenable position, engage the enemy with no victory or oppress the people.

130. Xunzi jishi, 15.271 (Hutton, 148; Knoblock, 2:222).

131. Xunzi jishi, 15.277 (Hutton, 152; Knoblock, 2:225).

132. Sunzi, 1.2. This point is indebted to McNeal, Conquer and Govern, $23-25$. 
Xiaocheng asks questions and Xunzi answers them. ${ }^{133}$ In other words, the authority of the teacher within Xunzi's text has shifted from Linwu to Xunzi.

The discussion then shifts the military regulations of a true king. According to Xunzi, a true king does not butcher inhabitants of a city, detain people arbitrarily, execute the young or elderly, destroy crops, incarcerate those who surrender, or pursue those who flee the battlefield. Even in punitive expeditions $(z h u)$, there is no retribution against the common people. As Xunzi puts it, a true king has punitive expeditions but no warfare (you zhu er wu zhan 誅而無戰). Nor does he butcher the inhabitants of conquered cities, conceal his army (qian jun 潛軍, move it by stealth), detain people, or commit his army to the field for more than one season at a time. ${ }^{134}$

It is again striking that the Sunzi would agree with most of these recommendations. An important exception is the use of stealth, which the Xunzi rejects as "unjust" and the Sunzi extols as effective strategy.

Another disagreement comes over the principle of an army taking advantage of the moment (shi). Xunzi's student Li Si 李斯 (c. 280-208 B.C.E.) asks about the victories of the state of Qin, and suggests that Qin's power is due not to benevolence and righteousness but to taking advantage of opportunities offered by the timely moment. Xunzi counters that these "opportunities" are not real; the real opportunity is to use benevolence and righteousness. ${ }^{135}$ Here Xunzi again asserts the priority of ren and yi over strategy and, by implication, deception. Although there is some agreement between the Sunzi and $X u n z i$ on military matters, the two diverge absolutely on the acceptability of deception, and Xunzi disparages the efficacy of Linwu's principles because they fail to meet his standard of ethics.

By contrast, some other Ru accepted military deception, and Xunzi's hostility to it was not accepted even by all Han Confucians. For example, in the "Exhibiting the Martial" (Zhi wu 指武) chapter of the Shuo yuan, Liu Xiang 劉向 (77-06 в.C.E.) uses the example of King Wen to argue for the need to understand deception:

文王興師伐徐，殘之。徐偃王將死，曰: 「吾賴於文德而不明武備，好行 仁義之道而不知詐人之心，以至於此。」夫古之王者其有備乎?

133. Xunzi jishi, 15.270.

134. Xunzi jishi, 15.278-79. Similar prohibitions appear in the Sima fa: not to pursue a fleeing enemy, to treat the wounded and sick with sympathy, and to pardon those who submitted (D1/45/3-5), and not destroy temples, buildings, forests, animals (wild or domestic), grains or tools (D1/45/23-25, trans. Sawyer, Seven Military Classics, 126-28).

135. Xunzi jishi, 15.280 . 
King Wen subsequently attacked $\mathrm{Xu}$ and defeated it. Just before he died, King Yan of Xu said: "I was too reliant on civil virtue and did not understand martial preparations. I was enamored of the dao of benevolence and righteousness but knew nothing of the mind of deceiving others [zha ren zhi xin] and so I have come to this!" Is it not clear that the kings of antiquity indeed made preparations! $!^{136}$

As Robin McNeal observes, Liu Xiang clearly identified as a Confucian, so his choice to write a chapter on military thought and to argue for its importance and the need to understand the workings of deception indicate that not all Confucians were inherently hostile to military thinking. ${ }^{137}$

\section{Political Deception}

I now argue that Xunzi's attack on military deception is part of a broader attack on what Xunzi considers incorrect uses of artifice in political and philosophical contexts: deceptive practices in seeking office, government, and the use of deceptive language in argument.

On Xunzi's view, an important function of sage government is to prevent deception in government and social practices, and he attacked three kinds of political deception: (1) dissolute practices and customs that undermine government, (2) fraudulent officials who misrepresent their abilities, and (3) deceptive officials in search of profit. Xunzi attacks licentious or dissolute (jian) behavior in the "Discourse on Music" (Yue lun 樂論):

\section{凡姦聲感人而逆氣應之, 逆氣成象而亂生焉; 正聲感人而順氣應之, 順氣 成象而治生焉。}

As a general rule, when dissolute sounds [jian sheng] stir people, a perverse qi responds to them; and when perverse qi takes full form, disorder is born from it. When correct sounds stir people, a compliant qi responds to them; and when compliant qi takes full form, order is born from it. ${ }^{138}$

The problem is that jian is inherently deceptive because its indirect effects lead to disorder. By contrast, sage kings prevent the people

136. Shuo yuan jiaozheng 說苑校證, ed. Xiang Zonglu 向宗魯 (Beijing: Zhonghua, 1987), 15.366-67. This story is probably based on a structurally similar narrative in Han Feizi 韓非子 (Sibu congkan 四部叢刊 edn.), 19.2a (“Wu du” 五冨 49). For discussion and a different translation see McNeal, Conquer and Govern, 20-21.

137. McNeal, Conquer and Govern, 22.

138. Xunzi jishi, 20.381 (Hutton, 220; Knoblock, 3.83). 
from engaging in dissolute or misleading customs (jian guai zhi su 姦怪 之俗). ${ }^{139}$ On this view, an important function of correct government is to eliminate dissolution and depravity (jian xie 姦邪) in order to ensure the livelihood and wellbeing of the people by protecting them from these indirect effects. ${ }^{140}$

A second type of political deception is the self-misrepresentation of deceitful persons (jian ren 姦人) who try to steal a false reputation for virtue and ministers who lie about their competence. ${ }^{141} \mathrm{~A}$ ruler who appoints such incompetents is merely benighted, but a minister who lies about his ability is a fraud (zha). When a benighted ruler appoints a fraudulent minister, destruction is sure to follow. ${ }^{142}$

A variant of self-misrepresentation is unwillingness to take a subordinate role. Xunzi criticizes such individuals as having "the mind of a fraud" (jian ren zhi xin 姦人之心); they seek the reputation of a sage but their intentions and actions reveal a deceptive mind (jian xin 姦心) and a deceptive way (jian dao 姦道). ${ }^{143}$ In his view, such people cannot deceive a junzi, just as (the expert assessor of horses) Bo Le 伯 樂 could not be deceived ( $q i)$ about horses. ${ }^{144}$

A third type of political deception puts economic profit over moral principle. Xunzi argues that deceptive individuals persist, despite their ultimate destructiveness, because rulers do not honor correct rituals and conduct. ${ }^{145}$ When rulers seek only profit, they treacherously deceive (dan zha 憚詐) their people for small profits within their state and they deceive their allies for large profits outside it.

Xunzi's move here is to link profit-seeking with stratagem. He argues that rulers who seek profit rely on "strategies of the opportune moment" (quan mou 權謀) and:

如是，則臣下百姓莫不以詐心待其上矣。上詐其下，下詐其上，則是上下 析也。

When it is like this, their ministers, subordinates, and the common people are never without a deceptive heart (zha xin) in their actions toward their

139. Xunzi jishi, 24.450.

140. Xunzi jishi, 12.237.

141. Xunzi jishi, 3.52.

142. Xunzi jishi, 12.242 .

143. Xunzi jishi, 7.113. Therefore, one should never accept orders to engage in treachery (wei jian 為姦, 7.110). Similar principles apply to ritual. Xunzi describes the "way of degenerates" (jian ren zhi dao 姦人之道) as the appearance of ritual and duty for the sake of effect (19.359 and 19.364). It is also a deceptive way (jian dao) to neglect one's duties or the people to gain advancement or nurture a reputation (10.189).

144. Xunzi jishi, 12.241.

145. Bu gui yi, bu jing yi 不貴義, 不敬義. Xunzi jishi, 16.305. 
superiors. Superiors deceive their subordinates and subordinates deceive their superiors, with the result that superiors and subordinates become separated. ${ }^{146}$

Thus rulers who favor opportunistic stratagems (quan mou) and love schemes (zha) endanger their states because their ministers and the people follow their examples and turn to subversion and rebellion. ${ }^{147}$ By contrast, if merchants and traders are honest and without deceit (wu zha), they can travel securely, goods circulate freely, and the country's needs are supplied. ${ }^{148}$

Xunzi further argues that straightforwardness and effort lead to success while deceit and artifice (zha wei 詐偽) lead to obstruction. ${ }^{149}$ Thus, avoiding deception is a practical matter, and the corrective to all three kinds of political deception is rule by a sage king or junzi. Xunzi argues that under sage rule, officials are not deceptive and the people do not adopt dissolute and strange customs (jian guai zhi su 姦怪之 俗). ${ }^{150}$ When rules and edicts are clear, even those who could profit do not put over deceptions ( $q i)$ on the people or the allies of a state. ${ }^{151}$

Xunzi also compares clear laws to objective standards: joining halves of tallies and contracts; counting sticks (chou 籌); the steelyard and balance beam; and units of measure such as the dou 斗 (peck) and gai 概 (level). These standards and instruments of precise measurement guarantee impartiality. By contrast, if a superior loves opportunistic strategies (quan mou) his ministers will be prone to deception (zha) and taking advantage of others (qi); and if he loves what is twisted and partial ( $q u$ si 曲私) his ministers and inferiors will take advantage of others. ${ }^{152}$ Xunzi considers the acme of governmental instruction (zheng jiao zhi ji 政教之極) to eliminate dissolute and strange practices (jian guai zhi shu 㚣怪之屬). ${ }^{153} \mathrm{He}$ also stresses the importance of environment in nurturing truthfulness or deception. A person in a good environment gains humaneness and morality without being aware of it. Those who live among bad people hear nothing but deceit, calumny, treachery, and artifice ( $q$ i wu zha wei 欺誣詐偽). ${ }^{154}$

\footnotetext{
146. Xunzi jishi, 11.205-6 (Hutton, 101; Knoblock, 2:152).

147. Xunzi jishi, 11.227, cf. 18.322 and 16.291.

148. Xunzi jishi, 11.228-29.

149. Xunzi jishi, 3.51.

150. Xunzi jishi, 24.450.

151. Xunzi jishi, 11.205.

152. Xunzi jishi, 12.230-31.

153. Xunzi jishi, 12.239. In domestic matters, he specifies as the duties of the one official to suppress lewdness and vice (fang yin chu xie 防淫除邪) among the people and to use the five punishments to prevent dissolute and evil behavior (jian xie 姦邪, 9.170).

154. Xunzi jishi, 23.499.
} 
In all these arguments, Xunzi's objection to jian (a term whose semantic range includes both dissolution and deception), zha, and ultimately to opportunistic stratagems (quan mou), is twofold. On the one hand, they cause disorder and destruction; but they have another and subtler psychological side effect. Xunzi claims that the use of deception undermines trust, even when it is used on a limited basis against enemies. Once trust is undermined, there is no rapport between superiors and subordinates, and the social hierarchy that is crucial to Xunzi's view of order is undermined.

\section{Philosophical Deception}

Xunzi's views on the positive use of artifice (discussed above) go hand in hand with a corresponding critique of what he considers the destructive use of artifice. He is vehement in his attack on philosophical opponents whose theories he considers deceitful and heterodox, including the use of deceitful language. These arguments occur throughout the Xunzi, and are of three broad kinds: (1) the claim that sages do not plan; (2) claims that deceptive language creates disorder, including the implication that names should be regulated; and (3) analogies between the instruments of craftsmen and $l i$ and $y i$.

They begin, perhaps surprisingly in "Against Physiognomy" (Fei xiang 非相). The general context of this chapter is Xunzi's attack on physiognomy on the ethical grounds that physiognomizing people's forms is inferior to assessing their heartminds. People cannot change their bone structure or face shape, but they can practice self-cultivation. The chapter concludes with an account of various kinds of people and modes of argument, presumably in an account of describing what kinds of person to employ. ${ }^{155}$ Xunzi describes the argumentation of the petty person, the junzi and the sage.

有小人之讋者, 有士君子之讋者, 有聖人之辯者: 不先慮, 不早 謀, 發之 而當, 成文而類, 。。。, 是聖人之辯者也。

155. One of the practical uses of physiognomy was selecting people, and also animals and inanimate objects, for employment. For a different classification of persons by physiognomy see Wang Chong 王充 (27-97 C.E.), Lun heng 論衡 (Weighing Discourses), 3 (“Gu xiang” 骨相). For an explicit classification of persons for purposes of employment, see Liu Shao's 劉邵 (3rd century C.E.) Renwu zhi 人物志 (Treatise on Human Abilities). For discussion of physiognomy see Richard J. Smith, Fortune-tellers and Philosophers: Divination in Traditional Chinese Society (Boulder: Westview Press, 1991), 173-220, and Lisa Raphals, Divination and Prediction in Early China and Ancient Greece (Cambridge: Cambridge University Press, 2013), 38-39, 9596 , and $142-46$. 
There is the argumentation of the petty, the argumentation of ritualist junzi and the argumentation of sages. [Sages] do not reflect [lï] ahead of time or make early plans [mou]; they send it out and it is appropriate, complete in form and [correctly] ordered [lei] ... this is the argumentation of sages. ${ }^{156}$

Sages do not ponder or plan because their argumentation is spontaneous and appropriate. At the other extreme is the argumentation of the petty:

\section{聽其言則辭辯而 無統，用其身則多詐而無功}

when you listen to their words they have propositions and eloquent discourse but without norms. If you employ them, they are strong on trickery but weak on accomplishment. ${ }^{157}$

They are the "deceitful man's hero" (jian ren zhi xiong 姦人之雄), the kind of man a sage king executes first, because he cannot change. ${ }^{158}$ This passage opposes the spontaneity of the sage to the forethought and strategy of the inferior and deceptive man, thereby linking planning, forethought, and strategy to deception and trickery. In this argument, the petty person is the analogue of the Sunzi general, whose hallmark is careful planning and using knowledge of the psychology of his opponent to anticipate his decisions and movements. The sage is the opposite of both. Here, Xunzi's spontaneous sage may resemble the agent of wu wei (discussed above). Nonetheless, Xunzi is entirely opposed to the indirect strategies of the Sunzi, which do not use the kind of indirection exemplified by wu wei.

The theme of opposing sagacity to trickery continues in "Against the Twelve Masters" (Fei shier $z i$ 非十二子), but the attack shifts from forethought and spontaneity to the use of deceptive language. Here the attack is on philosophical opponents who engage in deceptive language to create disorder in the world:

飾邪說，文姦言，以㴡亂天下

156. Xunzi jishi, 5.88 (Hutton, 39; Knoblock, 1:210). See also 25.464, which argues that treacherous deceit (jian zha 姦詐) always has disastrous consequences. Elsewhere, Xunzi recommends employing the purveyors of deceptive doctrines, theories, actions, and abilities (jian yan, jian shuo, jian shi, jian neng 姦言, 姦說, 姦事, 姦能) with official positions in the hope of improving them. See 9.149.

157. Xunzi jishi, 5.89 (Hutton, 39; Knoblock, 1:210-11).

158. Xunzi jishi, 5.89 (Hutton, 39; Knoblock, 1:210-11). 
they ornament perverse doctrines [xie shuo], embellish deceptive sayings [jian yan], and thereby disturb and disorder the world. ${ }^{159}$

Here Xunzi levels the charge of deception against a list of philosophical opponents that include Mozi (Mo Di 墨翟), Song Xing 宋鈃, Shen Dao 慎到, Hui Shi 惠施, and Deng Xi 鄧析. Each has enough principle behind his words to deceive and mislead the ignorant masses. ${ }^{160}$ Xunzi describes three deceptions forbidden by the sage kings of antiquity: deceptive undertakings (jian shi 㚣事), actions not appropriate for the people; deceptive minds (jian xin 㚣心), knowledge that does not fit the standards of the former kings; and deceptive theories (jian shuo 㚣說), which do not conform to ritual and moral principle (li and yi). On Xunzi's view, the greatest threat to social order comes from those who are wise but use their skill (qiao) for deception (zha), and apply precise language and discrimination to what is useless. Therefore the sage kings prohibited using deception for profit and using doctrines and distinctions for subversion. ${ }^{161}$

Xunzi's interest in social order also extends to attacks on philosophical doctrines and to those who have dissolute minds, follow dissolute daos, and promulgate deceptive theories. For example, in "The Accomplishments of the $\mathrm{Ru}^{\prime \prime}$ ( $R u$ xiao 儒效) he attacks vulgar $\mathrm{Ru}$ who promote themselves with exertion and artifice (wei 偽, in its negative sense), and are no different than Mozi. ${ }^{162} \mathrm{He}$ argues that one should pursue every kind of learning and doctrine that results in good order, but should abandon any other kind:

夫是之謂中說。事行失中, 謂之㚣事; 知說失中, 謂之姦道。㚣事、姦道, 治世之所棄，而亂世之所從服也。

This is called making doctrines conform to what is central. Undertakings and acts that lose what is central are called deceptive undertakings; knowledge and doctrines that lose what is central are called deceptive daos. Deceptive undertakings and deceptive daos are what a well-ordered age avoids, but a chaotic age follows and obeys. ${ }^{163}$

159. Xunzi jishi, 6.90 (Hutton, 40; Knoblock, 1:222-23). This kind of language occurs elsewhere in the Xunzi. For "ornamenting perverse doctrines" (shi xie shuo 飾邪說) see 4.60. For "treacherous statements" (jian yan) see 5.83, 9.151 and 22.422.

160. 其言之成理, 足以欺惑愚眾. Xunzi jishi, 6.91 .

161. 為詐而巧, 言無用而辯, 辯不惠而 察, 治之大殊也. Xunzi jishi, 6.98-99.

162. Xunzi jishi, 8.140-41.

163. Xunzi jishi, 8.124 (Hutton, 56; Knoblock, 2:72). 
By contrast, under the guidance of a junzi:

如是則姦言、姦說、姦事、姦謀、姦譽、姦㥲, 莫之試也; 忠言、忠說、 忠事、忠謀、忠譽、忠愬、莫不明通，方起以尚盡矣。

No one will advocate deceptive sayings, deceptive doctrines, deceptive undertakings, deceptive strategies, deceptive praise, or deceptive censure. No one will not comprehend loyal sayings, loyal doctrines, loyal undertakings, loyal plans, loyal praise, and loyal censure, and will promote them in all directions in order to elevate them to the highest degree. ${ }^{164}$

An extended attack on deceptive language appears in "Rectifying Names" (Zheng ming 正名), where Xunzi offers a definition of artifice (wei 偽) in its positive sense of deliberate conscious activity:

心慮而能為之 動謂之偽; 慮積焉, 能習焉, 而後成謂之偽。

When the mind reflects and the abilities act on it, it is called conscious and deliberate activity [wei]. When thoughts are accumulated and abilities are practiced so that something is completed, it is also called conscious and deliberate activity $[w e i] .165$

Xunzi argues that a true king regulates names carefully because skill at propositions and creating names on one's own disorder the correct use of names and create suspicion, discord, and litigation. Therefore the true kings called them "great deceptions" (da jian 大姦) and punished them as severely as forging tallies and tampering with weights and measures. ${ }^{166}$ Xunzi argues that unorthodox explanations and perverse sayings (xie shuo pi yan 邪說辟言) are the products of individual invention (shan zuo 擅作) and diverge from the correct dao. ${ }^{167}$ Xunzi opposes "correct dao" to the theories of the hundred schools:

\section{以正道而辨姦, 猶引繩以持曲直。是故邪說不能亂, 百家無所瓮。}

Using the correct dao to discriminate pernicious [jian] doctrines is like stretching the inked cord to regulate crooked and straight. As a result,

164. Xunzi jishi, 14.259 (Hutton, 141; Knoblock, 2:206).

165. Xunzi jishi, 22.412 (Hutton, 236; Knoblock, 3:127). The same view is reinforced at the beginning the following chapter, "People's Nature of Problematic" (Ren zhi xing e 人之性惡), where Xunzi categorically states that: “People's inherent nature is problematic; any goodness is a matter of conscious and deliberate activity" 人之性惡, 其善者 偽也。See 23.434 (Hutton, 248; Knoblock, 3:150-51). For another example see 19.366. 166. 故析辭擅作名, 以亂正名, 使民疑惑, 人多辨訟, 則謂之大姦. Xunzi jishi, 22.414.

167. Xunzi jishi, 22.422. 
heterodox theories [xie shuo] cannot cause disorder, and the hundred schools have nowhere to hide. ${ }^{168}$

Xunzi's arguments on deceptive language bear on two issues in contemporary Xunzi scholarship on Xunzi's view of name rectification and the nature of "names" (ming 名). One is the merits of a so-called "constructivist" position on naming and whether order (including the order created by naming) derives from natural categories or is a deliberate human "construction." This issue is related to Xunzi's views on artifice. On a constructivist interpretation of Xunzi, moral standards are human artifacts and not natural features of the world. 169

Xunzi's ming/names and the process of rectifying or attuning them are fundamentally ethical in nature, especially Xunzi's account of naming as a prerogative of a benevolent ruler. On a broadly constructivist account of Xunzi's zheng ming, deception in any of these senses profoundly interferes with the ethical context of name rectification. Such interference is all the more serious for Xunzi given his view that names do not have intrinsic appropriateness, and are thus vulnerable to misappropriation.

A second question is whether ming refers only to names in the sense of conventional labels or more broadly to concepts. Kurtis Hagen notes the widespread tendency of contemporary Chinese and Japanese scholarship on the Xunzi to understand ming as "concepts" (Chinese gainian 概念, Japanese gainen 概念). As Lin Lizhen 林麗眞 puts it, Xunzi's ming includes not only terms or concepts, but also "judgment" and "disputation."170 If we understand ming only as names, Xunzi's attacks on deceptive naming may seem overblown. But if we understand ming more broadly as concepts, judgments, and disputation, Xunzi's reasons for attacking deceptive language become clearer.

168. Xunzi jishi, 22.423 (Hutton, 175; Knoblock, 3:133).

169. Hagen disagrees with what he calls the "realist" view of several recent English-language studies of Xunzi. On this view, Xunzi held that there is only one correct standard for morality and that it exists independently of humans. Hagen takes the strongly constructivist position that Xunzi's "order" is a deliberate human construction and is not derived from inherent nature. Hagen ascribes this realist view to Robert Eno, P. J. Ivanhoe, and T. C. Kline III. See Hagen, "Artifice and Virtue," and The Philosophy of Xunzi: A Reconstruction (LaSalle: Open Court, 2007). For other views see Robert Eno, The Confucian Creation of Heaven: Philosophy and the Defense of Ritual Mastery (Albany: State University of New York Press, 1990), 146-52; Paul R. Goldin, Rituals of the Way: The Philosophy of Xunzi (Chicago: Open Court, 1999), 96, and "The Theme of the Primacy of the Situation in Classical Chinese Philosophy and Rhetoric," Asia Major (3rd ser.) 18.2 (2005), 1-25.

170. For a review of this scholarship see Hagen, The Philosophy of Xunzi, especially 50-84. For concepts see Hagen, The Philosophy of Xunzi, 63-64, and Lin Lizhen, "Xunzi" 荀子, in Zhongguo lidai sixiangjia 中國歷代思想家, ed. Wang Shounian 王壽南, vol. 1 (Taipei: Taiwan Shangwu, 1978), 65. 
Finally, Xunzi's hostility to philosophical deception is linked to a pervasive analogy he makes between ritual and morality (li and yi) and the precision implements of expert craftsmen. Several passages liken instruments for precise measurement to ritual (or dao) and oppose them to deception and fraud. A passage in the "Discourse on Ritual" (Li lun 禮論) opposes ritual and instruments of precise measurement to deception as manifested in theories of "hard and white" and "same and different":

故繩墨誠陳矣, 則不可欺以曲直; 衡誠縣矣, 則不可欺以輕重; 規矩誠設 矣, 則不可欺以方圓; 君子審於禮, 則不可欺以詐偽。

Thus, if the inked cord is set true [cheng], one cannot be deceived [qi] about crooked and straight. If the balance is hung true, one cannot be deceived about light and heavy. If compass and square are deployed true, one cannot be deceived about square and round. If the junzi thoroughly scrutinizes the rituals, he cannot be deceived by trickery and artifice [zha wei].171

Xunzi opposes this moral "measurement" to innovation, which he considers a kind of deception. Advocates of innovation argue that past circumstances are different from present ones, so innovation is necessary. Xunzi responds that the masses are deceived (qi) by such claims. If they can be easily deceived about what is before their own eyes, how much more easily can they be deceived about the ancient past. But a sage cannot be deceived. ${ }^{172}$

Finally, resistance to innovation is linked to Xunzi's view of culture as created by the "artifice" of sages (in the positive sense) but also as rooted in facilities generated by heaven. For this reason, the artifice of culture is not arbitrary, and must be protected carefully. On this view, the creation of culture was "generated" (sheng 生) by sages, rather than "created" (zuo 作). This view explains Xunzi's hostility to innovation, including his claim (contra the Mohists) that the most important figures in the history of technical innovation were not the inventors of instruments but those who had mastered the arts associated with them and employed them correctly. ${ }^{173}$ For Xunzi, the most important invention of the past was ritual and moral principles (li and yi), which allowed correct "measurement". 174

In summary, Xunzi attacks a range of philosophical deceptions by opponents who in his view cannot distinguish right and wrong, straight

171. Xunzi jishi, 19.356 (Hutton, 205; Knoblock, 3:61).

172. Xunzi jishi, 5.81-82.

173. For example, Xunzi jishi, 21.401-2 and 23.437-39.

174. For this argument see Puett, Ambivalence of Creation, 69-73. 
and crooked, or the causes of order and chaos. Instead, they take up strange theories (guai shuo 怪說) and extraordinary propositions (qi ci 奇辭), and lack ritual or rectitude. "Such," he laments, "are the theories of the degenerate people of a disordered age."175 Elsewhere he links this kind of behavior to two of what Confucius described as five kinds of evil: (1) a mind that is penetrating but treacherous (xin da er xian 心達 而險) and (2) using techniques of discrimination to defend false doctrines (yan wei er bian 言偽而辯). ${ }^{176}$

\section{Conclusion}

In conclusion, the Sunzi's attitude toward deception distinguishes it from other bingfa texts, from texts that praise indirection by wu wei, and from texts that explicitly attack deception and/or indirection. Deception is clearly central to the military philosophy of the Sunzi, and it is the only bingfa text that explicitly and consistently theorizes deception as the central principle of a strategy-centered approach to warfare.

The Sunzi is also singular in its treatment of indirection. Indirection, especially as linked to $w u$ wei, is represented as practically and philosophically important in the Analects, Daode jing, Guanzi, and Zhuangzi, among others; and it is often linked to what the Guanzi calls "the arts of the heartmind" (xin shu). We might be tempted to position the Sunzi and several other Militarist texts at one end of a spectrum of texts that advocate the use of indirection as a central aspect of efficacious action. At the other end of that spectrum are texts that centrally advocate indirect action described as wu wei. The indirection of the Sunzi account of efficacy is fundamentally different in kind from "wu wei" accounts.

Some recent scholarship suggests that the indirection of wu wei is more a state of mind than a mode of action, and the same might be hypothesized of the deceptive indirection of the Sunzi. ${ }^{177}$ In the Sunzi, indirect action is grounded in the use of deception to mislead an opponent in order to gain advantage. The Sunzi is distinctive for this espousal of deception and cunning. It does this not by repeatedly advocating these concepts, but by repeated examples that show or suggest their

175. Luan she jian ren zhi shuo 亂世姦人之說. Xunzi jishi, 21.409.

176. Xunzi jishi, 28.521.

177. For example, some contemporary psychologists include a "Machiavellianist" type within a taxonomy of so-called "dark personalities." See D. L. Paulhus and K. M. Williams, "The Dark Triad of Personality: Narcissism, Machiavellianism, and Psychopathy," Journal of Research in Personality 36 (2002), 556-63, and D. L. Paulhus, "Toward a Taxonomy of Dark Personalities," Current Directions in Psychological Science 23.6 (2014), 421-26. 
efficacy. Taken together, the Sunzi's continuities with texts that advocate indirection and its opposition to texts that reject deception show its philosophical distinctiveness.

If the Sunzi represents one extreme on a continuum of texts that advocate deception and indirection based upon it, Xunzi represents another extreme of hostility to both deception and many uses of indirection. The Xunzi opposes the military philosophy of the Sunzi by claiming that the latter's version of efficacy is inferior to moral and ethical priorities. This debate is part of a much larger attack on deception and indirection.

To compare their attitudes toward deception it is useful to return to the general discussion of deception with which this article began. (It should be emphasized that a perspective from analytic philosophy is introduced because it has useful explanatory force.) Discourse on deception within contemporary analytic philosophy emphasizes that deception is (1) always intentional, (2) successful prima facie, and (3) not limited to language. It can also involve "bullshit": the misrepresentation of one's intentions and attitudes, rather than directly false statements. Comparing the Sunzi and Xunzi with respect to these points reveals some predictable areas of difference, but also some interesting areas of agreement.

Both texts agree on several points about deception. Both emphasize the intentional nature of deception, but from opposite points of view. The Sunzi is very concerned for how to do it well. Xunzi hates it precisely because it is deliberate, and by implication, its consequences for the social order are deliberate also.

Second, both the Sunzi and Xunzi acknowledge the "success" component of deception. The Sunzi does so by repeated instruction on what kinds of ruse to use in what circumstance and how to pull them off correctly. Skills associated with strategy, forethought, ruse, and effective deception are central to that enterprise. For Xunzi, acknowledgment of successful deception takes the form of complaints that the people are misled, by political deceptions especially. These include dissolute practices that undermine political order, self-misrepresentation by deceptive officials, and putting profit over morality by deceptive rulers.

Finally, both the Sunzi and Xunzi are deeply concerned by what Frankfurt calls bullshit, but for very different reasons. The Sunzi's detailed recommendations on how to mislead an enemy general qualify as bullshit par excellence, though they are probably not what Frankfurt intended by the term in his own influential analyses.

An important difference is the two texts' attitudes toward language. The Sunzi mentions deceptive language, including spreading false information and the use of spies, but its focus is on deceptive actions that mislead the perceptions or manipulate the emotions of an enemy 
general. By contrast, deception by language, especially argumentation, is a major focus of the Xunzi, ranging from deliberately misapplied names to the pernicious sayings and doctrines of opponents.

Taken together, the above comparisons show that the Sunzi stands in sharp contrast to a group of texts that accept indirection but explicitly reject deception and cunning. These include the Analects and Mencius, but most prominently and pervasively, the Xunzi, a text that also includes a chapter on debating military matters. For these reasons we may usefully think of the Sunzi and the Xunzi as philosophical antipodes.

孫子與荀子的爭鋒: 對欺騙和間接的兩種觀點

\section{瑞麗 \\ 提要}

本文探討了關於欺騙的倫理與功效的兩種觀點。對欺騙和間接戰術的 推崇是孫子思想中廣為人知的一點。中國古代的兵書往往對欺騙持兩 種態度: 一或全然否定, 一或僅僅將之視為一種實用而重要的戰略工 具, 而孫子對於欺騙不遺餘力的褒揚可謂獨樹一幟。在荀子看來, 無 論是在民用還是軍用的語境下, 欺騙都應被否定。孫子與荀子對於欺 騙和間接的不洞態度代表了中國哲學思想中截然相反的兩極。

Keywords: Sunzi, Xunzi, indirection, deception, Military philosophy 孫子, 荀子, 無為, 偽 